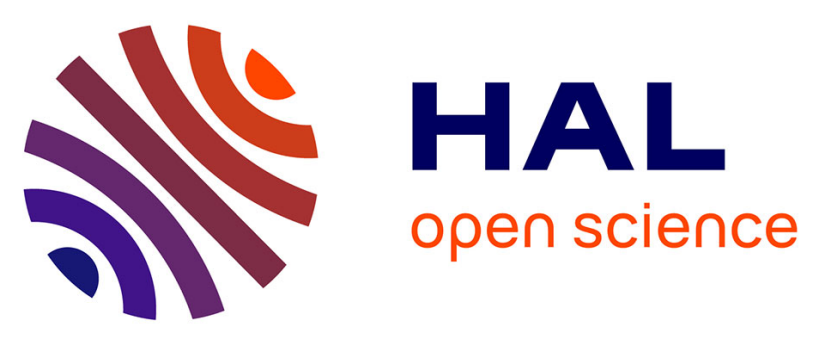

\title{
Quantification of silanol sites for the most common mesoporous ordered silicas and organosilicas: total versus accessible silanols
}

Matthias Ide, Mohamad El-Roz, Els de Canck, Aurélie Vicente, Tom Planckaert, Thomas Bogaerts, Isabel van Driessche, Frederic Lynen, Veronique van Speybroeck, Frédéric Thybault-Starzyk, et al.

\section{To cite this version:}

Matthias Ide, Mohamad El-Roz, Els de Canck, Aurélie Vicente, Tom Planckaert, et al.. Quantification of silanol sites for the most common mesoporous ordered silicas and organosilicas: total versus accessible silanols. Physical Chemistry Chemical Physics, 2013, 15 (2), pp.642-650. 10.1039/c2cp42811c . hal-01963802

\section{HAL Id: hal-01963802 https://hal.science/hal-01963802}

Submitted on 5 Oct 2021

HAL is a multi-disciplinary open access archive for the deposit and dissemination of scientific research documents, whether they are published or not. The documents may come from teaching and research institutions in France or abroad, or from public or private research centers.
L'archive ouverte pluridisciplinaire HAL, est destinée au dépôt et à la diffusion de documents scientifiques de niveau recherche, publiés ou non, émanant des établissements d'enseignement et de recherche français ou étrangers, des laboratoires publics ou privés. 


\section{Quantification of Silanol Sites for the Most Common Mesoporous Ordered Silicas and Organosilicas: Total Versus Accessible Silanols.}

\begin{tabular}{|r|l|}
\hline Journal: & The Journal of Physical Chemistry \\
\hline Manuscript ID: & jp-2012-050884 \\
\hline Manuscript Type: & Article \\
\hline Complete List of Authors: & $\begin{array}{r}\text { Ide, Matthias; University of Ghent, Inorganic and Physical Chemistry } \\
\text { El-Roz, Mohamad; ENSICAEN, Université de Caen, CNRS, Laboratoire } \\
\text { Catalyse et Spectrochimie } \\
\text { De Canck, Els; Ghent University, Inorganic and Pysical Chemistry } \\
\text { Vicente, Aurelie; ENSICAEN, Université de Caen, CNRS, Laboratoire } \\
\text { Catalyse et Spectrochimie } \\
\text { Planckaert, Tom; University of Ghent, Inorganic and Physical Chemistry } \\
\text { Bogaerts, Thomas; University of Ghent, Inorganic and Physical Chemistry } \\
\text { Lynen, Frederic; Ghent University, Organic chemistry } \\
\text { Van Speybroeck, Veronique; Ghent University, Center for Molecular } \\
\text { Modeling } \\
\text { Thibault-Starzyk, Frederic; CNRS, ENSICAEN - Laboratoire Catalyse et } \\
\text { Spectrochimie } \\
\text { Van Der Voort, Pascal; Ghent University, Department of Inorganic and } \\
\text { Physical Chemistry }\end{array}$ \\
\hline
\end{tabular}




\title{
Quantification of silanol sites for the most common
}

\author{
mesoporous ordered silicas and organosilicas: total
}

\section{versus accessible silanols.}

\author{
Matthias Ide, ${ }^{a}$ Mohamad El-Roz ${ }^{b}$ Els De Canck ${ }^{a}$, Aurélie Vicente ${ }^{b}$ Tom Planckaert ${ }^{a}$, Thomas \\ Bogaerts ${ }^{a, e}$, Isabel Van Driesschec, Frédéric Lynend, Veronique Van Speybroeck ${ }^{e}$, Frédéric Thybault- \\ Starzyk ${ }^{b}$ and Pascal Van Der Voort ${ }^{a, *}$
}

${ }^{a}$ COMOC, Center for Ordered Materials, Organometallics and Catalysis, Department of Inorganic and Physical Chemistry, Ghent University, Krijgslaan 281 (S-3), 9000 Ghent, Belgium. Fax: +32 9264 4983, Tel: +3292644442

${ }^{b}$ Laboratoire Catalyse et Spectrochimie (LCS), Université de Caen, 6, Bd du Marechal Juin, 14050 Caen Cedex, France.

c Department of Inorganic and Physical Chemistry, Sol-gel Centre for Research on Inorganic Powder and Thin film Synthesis, University of Ghent, Krijgslaan 281 (S-3), 9000 Ghent, Belgium.

dDepartment of Organic Chemistry, Laboratory of Separation Sciences, University of Ghent, Krijgslaan 281 (S-4), 9000 Ghent, Belgium.

eCenter for Molecular Modeling, Ghent University, Technologiepark 903, B-9052 Zwijnaarde, Belgium.

E-mail: Pascal.Vandervoort@ugent.be 


\section{RECEIVED DATE (to be automatically inserted after your manuscript is accepted if required according to the journal that you are submitting your paper to)}

IR and NMR spectroscopy were used to characterize the silanol content in the most common mesoporous ordered silicas: MCM-41, MCM-48 SBA-15 and SBA-16. The total silanol number and the amount of surface silanols, which can be reached by various common chromatographic silanes, are calculated for the most widespread mesoporous templated silicas (MTS). In addition, a comparison between MCM-41 prepared by spray dried synthesis (MCM-41(SD)) and by hydrothermal synthesis (MCM-41) has been performed in order to present the effect of the synthesis methods on the MCM-41 properties. The characterization of an ethene bridged Periodic Mesoporous Organosilica (PMO) is discussed in this paper. The results were compared with those of Nucleosil used as commercial silica material. The complete distribution of surface and bulk silanols, and of isolated, geminal and vicinal silanols for all these materials is presented. To complete the research and obtain a deeper understanding of the grafting reactions, theoretical calculations were performed to determine the geometry of the carbon substituents. There are distinct differences in the silanol contents and distribution of all these materials; we show that these differences are mostly due to the synthesis conditions, the pore architecture and the wall thickness. Remarkably, unlike silica gels or silica sols, up to $70 \%$ of the silanols on ordered mesoporous silicas and more than $90 \%$ of the silanols of a mesporous organosilica is not accessible for small silanes.

KEYWORDS: Silanol number, ordered mesoporous materials, grafting, spray dried 


\section{Introduction}

The silanol number is a topic of interest and discussion since the 1950s until today. A good knowledge of the number of silanols on the silica surface is important in areas such as catalysis and adsorption. Also in emerging disciplines, such as drug delivery, tissue engineering by silica and organosilica scaffolds, thin film technology, etc. , the exact knowledge of the silanol number is needed or at least desirable. More specifically, in the field of chromatography, the silanol groups are of major importance for two reasons. In the first place, they are the anchoring point for the stationary phase functional groups. In this way, they have a direct influence on the retention mechanism of a chromatographic packing material. Secondly, once the functional groups are grafted on the silica surface, it is important that the residual silanol groups are removed from the system by endcapping with e.g. a trimethylsilylgroup. This, because residual silanol groups can, for example, lead to asymmetric or tailing signals in the chromatography of basic compounds. On the other hand, in a technique such as capillary electrochromatography (CEC) the remaining silanol groups help to create the electro osmotic flow, which drives the separation. [1]

The determination of the silanol number is complicated by the easy adsorption of water on silica. Therefore the exact quantification with MAS NMR, FTIR, selective chemisorption, deuterium exchange and mass spectroscopy is always complicated by the need for a very controlled atmosphere during sample treatment and measurement. Many models appeared in the 1970s and 80s on the determination of the silanol number of silica gels or fumed silicas.[2-4] For silica gels, many different datasets on the silanol number are available, with a large number originating from the former USSR. The silanol number is often referred to as the Zhuravlev number, in honor of his pioneering work in the field.[5-8] In 1995, Van Der Voort et al. published an overview of the silanol number of silica gels as a function of temperature with a specification of the number of isolated, geminal and vicinal silanols.[9] However for the mesoporous ordered (organo)silica 
materials, prepared by anionic, cationic or neutral templates at a wide range of pHs and temperatures, this table is no longer applicable, as we will show in this work.

Several standard methods have been used to characterize and quantify the density of silanol groups of both amorphous and mesostructured silica materials. Thermogravimetric analyses[10], diffuse reflectance fourier transform infrared spectroscopy (DRIFT) [11-12], ${ }^{29} \mathrm{Si}$ and ${ }^{1} \mathrm{H}$ NMR [1314], microcalometry [15] or a combination of these techniques were combined with the use of probing molecules such as silanes [16-19], water [20-22] or pyridine [23] adsorption. The silanol concentrations that have been reported on MCM-41 are hardly comparable, due the fact that each paper reports a different silanol number for MCM-41 without considering synthesis and analysis parameters. [24-29] For example the silanol number is strongly dependent on the temperature of any post synthesis treatment. [9] However in six different reports where MCM-41 was post treated at the same temperature, silanol values varying from 0.9 up to 3 groups per nm ${ }^{2}$ were found. [10, 23, 30-33] After a thorough search of literature no systematic determination of the silanol number of periodic mesoporous organosilicas could be found. Also a systematic comparison of the most common mesoporous ordered silicas is not available in literature.

Therefore in this contribution, we report the accessible surface silanols for various chromatographic relevant functional groups together with the total amount of silanol groups, whether they are on the surface or not. We believe this information will be useful for many colleagues in various fields of research and for the chromatographic colleagues in particular. The silanol numbers have been quantified using previously described IR techniques [34] combined with solid state NMR and elemental analysis of grafting procedures.

2 Experimental

2.1 Materials 
Nucleosil 300-5 (mean pore diameter: $30 \mathrm{~nm}$; $5 \mu \mathrm{m}$ particle size) was purchased from MachereyNagel. Hexadecyltrimethylammonium bromide (99\%) (CTAB), tetraethyl orthosilicate (98\% reagent grade) (TEOS), ammonium hydroxide, potassium chloride (>99\%) acetonitrile (HPLC grade), 1-butanol (99.8\%), pluronic $\mathrm{PEO}_{20} \mathrm{PPO}_{70} \mathrm{PEO}_{20}$ (P123), pluronic $\mathrm{PEO}_{106} \mathrm{PPO}_{70} \mathrm{PEO}_{106}$ (F127), Vinyltriethoxysilane (VTES) and Grubbs' $1^{\text {st }}$ generation were acquired at Sigma-Aldrich. Fuming hydrochloric acid $37 \mathrm{w} / \mathrm{w} \%$ was purchased from Roth, anhydrous toluene (> 99,9\%) for the grafting was obtained from Acros. n-Octadecyldimethylchlorosilane(97\%), nOctyldimethylchlorosilane and Bis(trimethylsilyl) amine were supplied by ABCR. All chemicals were used without further purification.

\subsection{Synthesis of the supports}

SBA-15 [35], SBA-16 [36], MCM-41 [37], MCM-48 [38], spray dried MCM-41 [39] and ethene bridged periodic mesoporous organosilica (PMO) [40] were all prepared according to methods found in literature. All syntheses were carried out under hydrothermal conditions, except for the spray dried MCM-41 type material, denoted as MCM-41 (SD). Two types of pore systems were synthesized, a hexagonal and a cubical pore system. MCM-41, MCM-41(SD), SBA-15 and the ethene bridged PMO have a hexagonal pore system. The MCM-48 and the SBA-16 both exhibit a cubical pore system. All the synthesis procedures can be found in the supplementary information. Nucleosil 300-5 is commonly used as a packing material in chromatographic HPLC applications. MCM-41, MCM-41(SD), MCM-48, SBA-15 and SBA-16 were calcined at $550{ }^{\circ} \mathrm{C}$ for 6 hours with a heating rate of $1.5^{\circ} \mathrm{C} / \mathrm{min}$ to remove the surfactant. The surfactant of the ethene bridged PMO was removed by a soxhlet extraction with acetone at $120^{\circ} \mathrm{C}$. [41] After the synthesis all the samples were kept dry and under inert atmosphere.

\subsection{Grafting procedures}


Prior to grafting water was removed from the samples by a heating procedure at $120^{\circ} \mathrm{C}$ under vacuum conditions for 24 hours.

Three different silanes with increasing tail length were used as probing molecules to determine the amount of accessible silanol sites on the surface of the different silica materials. A trimethylsilyl (C3), an octyldimethylsilyl (C8) and an octadecyldimethylsilyl (C18) group were anchored to the surface. The reaction time was $24 \mathrm{~h}$ for all the grafting reactions and the composition of the final mixture was $0.5 \mathrm{~g}$ silica $/ 1.4 \mathrm{mmol}$ silane $/ 30 \mathrm{ml}$ solvent. The trimethylsilyl and the octyldimethylsylil group were grafted by means of hexamethyldisilazane and octyldimethylchlorosilane, respectively, in dry acetonitrile and left to stir for 24 hours at room temperature. The octadecyldimethylsilyl group was grafted by means of octadecyldimethylchlorosilane in dry toluene under the same conditions as cited above.

After reaction the materials were filtered off, washed thoroughly with acetonitrile or toluene and acetone, dried at $120^{\circ} \mathrm{C}$ under vacuum and analyzed with elemental analysis.

\subsection{Characterization}

Nitrogen adsorption experiments were measured at $-196{ }^{\circ} \mathrm{C}$ using a Belsorp mini II gas analyzer. X- ray powder diffraction (XRPD) patterns were collected on an ARL X'TRA X-ray diffractometer with $\mathrm{Cu} \mathrm{K \alpha}$ radiation of $0.15418 \mathrm{~nm}$ wavelength and a solid-state detector. Elemental analyses (C, H, N) were performed on a Thermo Scientific Flash 2000 CHNS-O Analyzer.

For the determination of the silanol number, a special transmission FTIR setup was used. 


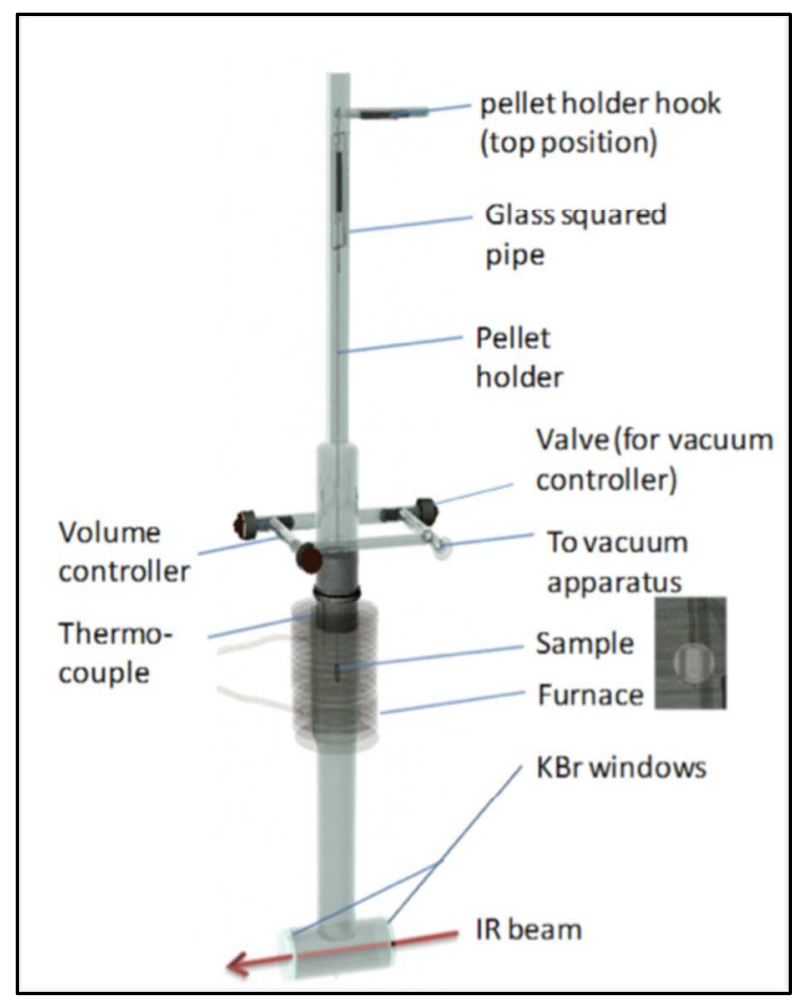

Figure 1: The In-Situ IR-cell used to determine the silanol number of the materials.
The silica powders were pressed $\left(\sim 10^{7} \mathrm{~Pa}\right)$ into self-supported discs $\left(2 \mathrm{~cm}^{2}\right.$ area, $\left.7-8 \mathrm{mg} / \mathrm{cm}^{2}\right)$. They were placed in a cell equipped with $\mathrm{KBr}$ windows. A movable quartz sample holder allowed placing the pellet in the infrared beam, for recording spectra, and moving it into a furnace at the top of the cell for thermal treatment (see figure 1).

A Nicolet 6700 IR spectrometer equipped with a DTGS detector and an extended-KBr beam splitter was used for the acquisition of spectra recorded in the $400-5500 \mathrm{~cm}^{-1}$ range. Spectra were recorded at 4 $\mathrm{cm}^{-1}$ and 250 scans were co-added for each spectrum. Solid-state MAS NMR spectra were recorded on a Bruker Avance-400 (9.4T) spectrometer using 4 mm-OD zirconia rotors and a spinning frequency of $12 \mathrm{kHz}$. Single pulse excitation ( $30^{\circ}$ flip angle) and $20 \mathrm{~s}$ recycling delay was used for ${ }^{29} \mathrm{Si}$ MAS NMR experiments. $\left\{{ }^{1} \mathrm{H}\right\}-{ }^{29} \mathrm{Si}$ cross-polarization (CP) MAS experiments were performed using a contact time of $6 \mathrm{~ms}$ and a recycle time of $3 \mathrm{~s}$. Tetramethylsilane (TMS) was used as chemical shift reference ${ }^{29}$ Si nuclei.

\section{Results and discussion}

In order to simplify the discussion of the effect of the synthesis method on the material properties, the main differences between synthesis conditions and template removal are summarized in Table 1. 
Table 1: Overview of the materials: synthesis conditions and template removal.

\begin{tabular}{|l|l|l|l|}
\hline & \multicolumn{2}{|l|}{ Synthesis conditions } & $\begin{array}{l}\text { Template } \\
\text { removal }\end{array}$ \\
\hline SBA-15 & Hydrothermal & Acid & Calcination \\
\hline SBA-16 & Hydrothermal & Acid & Calcination \\
\hline MCM-41 & Hydrothermal & Base & Calcination \\
\hline MCM-48 & Hydrothermal & Base & Calcination \\
\hline MCM-41(SD) & Spray dried & Acid & Calcination \\
\hline EthenePM0 & Hydrothermal & Acid & Extraction \\
\hline
\end{tabular}

As mentioned above in the experimental part, the template removal has been performed by conventional calcination at $550^{\circ} \mathrm{C}$, except the PMO which was activated by soxhlet extraction at $120^{\circ} \mathrm{C}$ using acetone as solvent. The comparaison of the MCM-41 and MCM-41(SD) allows understanding the effect of hydrothermal and spray dried synthesis on the material behavior. For comparison, Nucleosil was purchased from Macherey-Nagel in order to be used as reference.

\subsection{The pore properties of the materials}

Three types of pore structures were synthesized, a hexagonal P6/mm structure (MCM-41-HT, MCM-41-SD, SBA-15 and ethene bridged PMO) and two cubical structures (MCM-48 (Ia3d) and SBA-16 (Im3m)). Additionally there are substantial differences between MCM type materials and SBA type materials in general. MCM type materials exhibit pore sizes between 2 and $4 \mathrm{~nm}$ with a wall thickness of about $1 \mathrm{~nm}$. No significant difference in the pore properties can be discerned between the hydrothermally synthesized and the spray dried MCM-41 material. This is small compared to the SBA and PMO materials where pore sizes vary between 6 and $10 \mathrm{~nm}$ with a wall thickness between 3 and $7 \mathrm{~nm}$. This difference in pore size properties can be assigned to the use of a different surfactant as pore generating agent. An additional property of the materials 
synthesized with Pluronic surfactants is that next to mesopores also micropores are generated in the walls.

The various pore properties are shown in table 2 , the surface area $(\mathrm{SA}(\mathrm{BET}))$, pore volume $\left(\mathrm{V}_{\mathrm{p}}\right)$ and pore diameter $\left(d_{p}\right)$ were determined with $N_{2}$-sorption. The unit cell $\left(a_{0}\right)$ was determined from the XRD spectra of the materials and the wall thickness (h) was calculated with the following formulas:

MCM-41, SBA-15 and ethene bridged PMO[42]: $h=a_{0}-0.95 d_{p}$;

$$
\operatorname{MCM}-48[43]: h=\frac{a_{0}}{3.0919}-\frac{d_{p}}{2} ;
$$

SBA-16[44]: $h=\frac{\sqrt{3}}{2} a_{0}-d_{p}$

Note that for Nucleosil no pore diameter could be calculated due to its broad pore size distribution. This material is also unordered, and does not produce any XRD reflections.

Table 2: The pore properties of the various materials, with $S A_{B E T}$ the surface area, $V_{p}$ the pore volume, $\mathrm{d}_{\mathrm{p}}$ the pore diameter, $\mathrm{a}_{0}$ the unit cell and $\mathrm{h}$ the wall thickness.

\begin{tabular}{|l|lll|l|l|l|}
\hline Material & $\mathrm{SA}_{\mathrm{BET}}$ & $\mathrm{V}_{\mathrm{p}}$ & $\mathrm{d}_{\mathrm{p}}$ & $\mathrm{a}_{0}$ & $\mathrm{~h}$ \\
\hline & $\mathrm{m}^{2} / \mathrm{g}$ & $\mathrm{cm}^{3} / \mathrm{g}$ & $\mathrm{nm}$ & $\mathrm{nm}$ & $\mathrm{nm}$ \\
\hline SBA-15 & 656 & 0.7 & 6.9 & 10.7 & 4.2 \\
\hline SBA-16 & 738 & 0.6 & 6.2 & 14.6 & 6.4 \\
\hline MCM-41 & 1144 & 0.6 & 2.9 & 3.8 & 1.1 \\
\hline MCM-48 & 1293 & 0.8 & 2.8 & 7.3 & 1.0 \\
\hline MCM-41(SD) & 719 & 0.4 & 2.9 & 3.6 & 1.2 \\
\hline EthenePMO & 923 & 1.0 & 6.2 & 9.0 & 3.1 \\
\hline Nucleosil & 88 & 0.4 & - & - & - \\
\hline
\end{tabular}

3.2 The total concentration of silanol-groups from in-situ IR 
According to the literature [34], adsorbed water species are characterised by a $\delta \mathrm{H}_{2} \mathrm{O}$ band near $1630 \mathrm{~cm}^{-1}$ (Figure 2 - a). The spectrum of the dried sample (Figure 2 - b) presents a narrow band at $3740 \mathrm{~cm}^{-1}$ characterizing isolated silanol groups. The band of inner hydroxyl group is situated at about $3650 \mathrm{~cm}^{-1}$. The band of H-bonded hydroxyl groups is situated at about $3540 \mathrm{~cm}^{-1}$. From the area of the $(v+\delta) \mathrm{OH}$ band at $4560 \mathrm{~cm}^{-1}$ (inset of figure 2), we have estimated the total concentration of Si-OH groups (both on the surface and in the wall) (Table 3, column 1), using the methodology described in reference [34]. In this way, there is no bias from a possible contribution of physisorbed water.

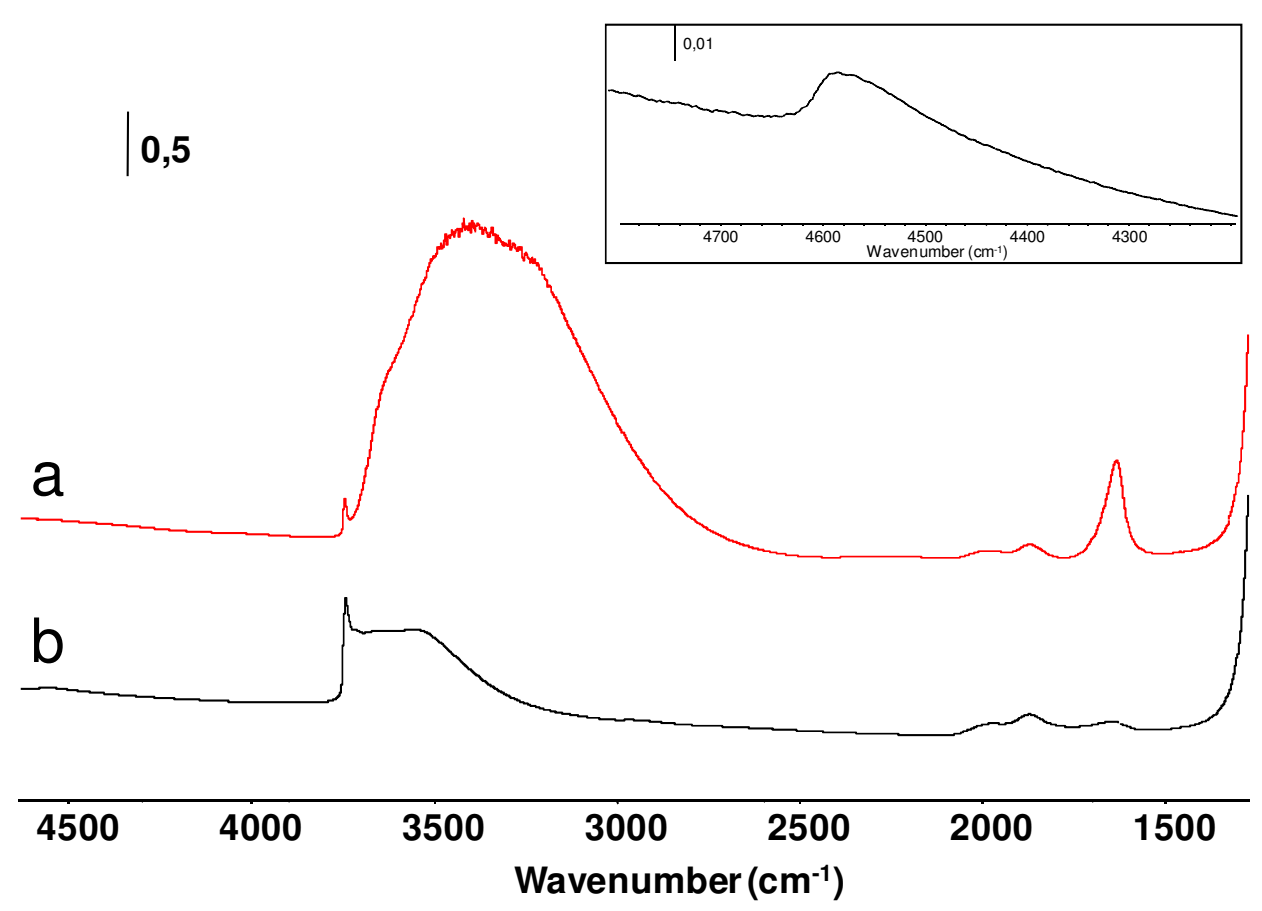

Figure 2: Infrared spectra of SBA-15 sample in the 1500-5500 $\mathrm{cm}^{-1}$ range. a) Spectrum recorded under atmosphere conditions. b) Spectrum recorded after degassing.

\subsection{The various $\mathrm{OH}$ species according to MAS ${ }^{29} \mathrm{Si}$ NMR}

The $\mathrm{OH}$ species were quantified using MAS ${ }^{29} \mathrm{Si}$ NMR and the NMR band was located using CP MAS ${ }^{1} \mathrm{H}{ }^{29} \mathrm{Si}$. It is well known that ${ }^{29} \mathrm{Si} \mathrm{MAS}$ NMR is a sensitive technique to show the presence of different types of silicon sites in solids. In siliceous zeolite, silicon species are depicted as $\mathrm{Q}^{4}$ if the silicon is surrounded with four -O-Si groups, $\mathrm{Q}^{3}$ if one -O-Si group is replaced with one OH group, 
etc... These species present a very different chemical shift. The CP MAS $\left\{{ }^{1} \mathrm{H}\right\}-{ }^{29} \mathrm{Si}$ is a technique that highlights the presence of $\mathrm{OH}$ groups, which elucidates the ${ }^{29} \mathrm{Si} \mathrm{MAS} \mathrm{spectrum.} \mathrm{Just} \mathrm{as} \mathrm{it} \mathrm{is} \mathrm{the}$ case with the in-situ IR measurements, solid state NMR is a bulk analysis tool. It measures both the silanols on the surface and in the walls of the materials.

\subsubsection{The $\mathrm{OH}$ species for MCM and SBA materials}

First the pure silica materials (MCM and SBA-type) are compared. Spectra obtained by direct polarization and by CP-MAS are presented in figure $3 \mathrm{~A}$ and $\mathrm{B}$, respectively. Figure 4 depicts the NMR spectra for the silica materials with the $\mathrm{Q}^{2}, \mathrm{Q}^{3}$ and $\mathrm{Q}^{4}$ sites, as well as schematic explanation of these three species. It is interesting to see differences in intensity and width in the three $\mathrm{Q}^{\mathrm{n}}$ peaks in the direct spectra (figure $3 \mathrm{~A}$ ) as well as in the cross polarized spectra (figure 3B). The amount of $\mathrm{SiO}_{2}(\mathrm{OH})_{2}$ (geminal silanol), $\mathrm{SiO}_{3} \mathrm{OH}$ (single silanol) and $\mathrm{SiO}_{4}$ species, respectively, are then estimated for all samples by using deconvolution, as presented in figure 3, and comparison with peak intensity in CPMAS.
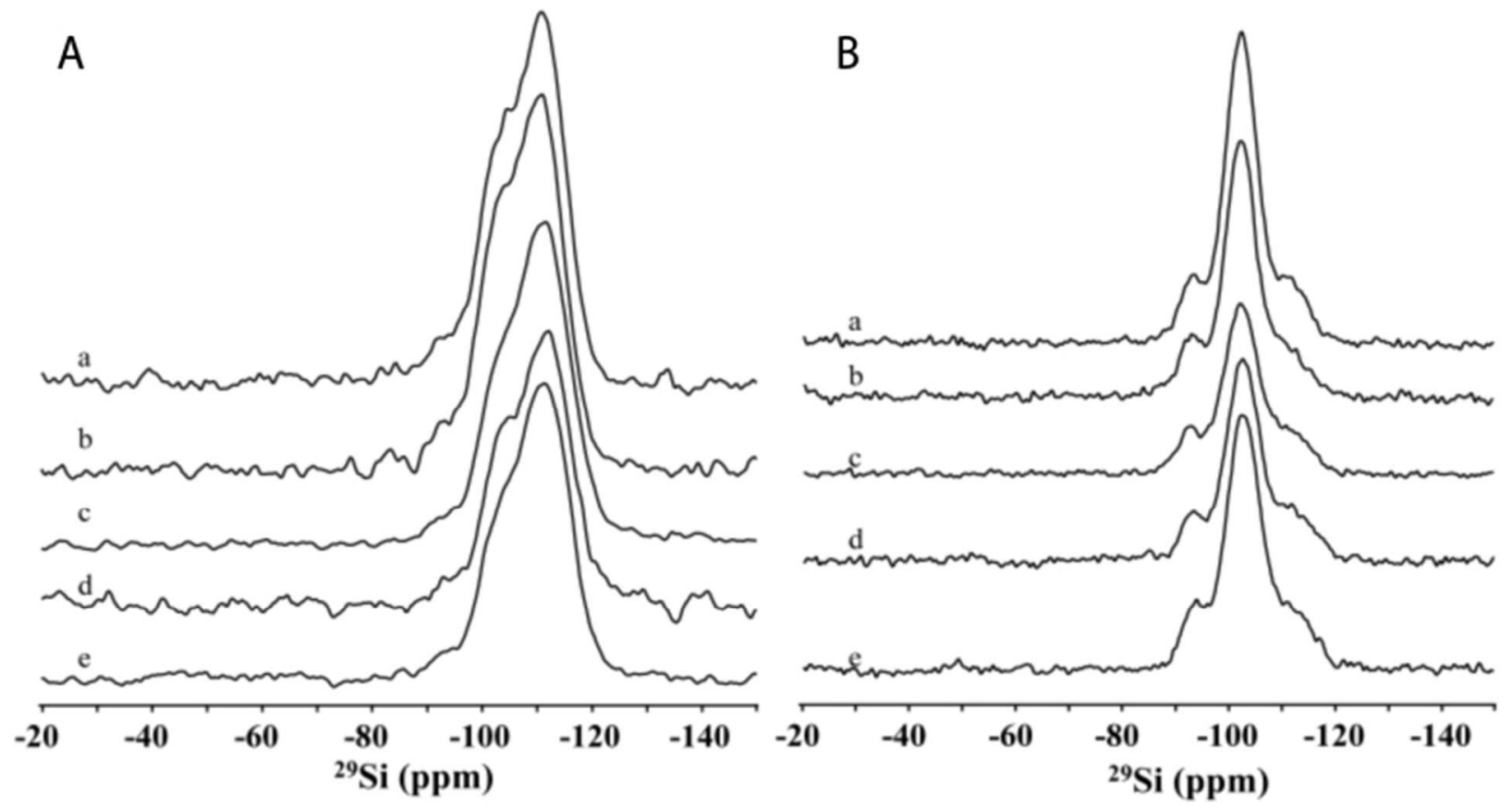

Figure 3: The ${ }^{29}$ SiMAS NMR (A) and the CPMAS $\left\{{ }^{1} \mathrm{H}\right\}-29 \mathrm{Si}(\mathrm{B})$ spectrum for MCM-41HT (a), MCM48 (b), MCM-41SD (c), SBA-15 (d) and SBA-16 (e). 

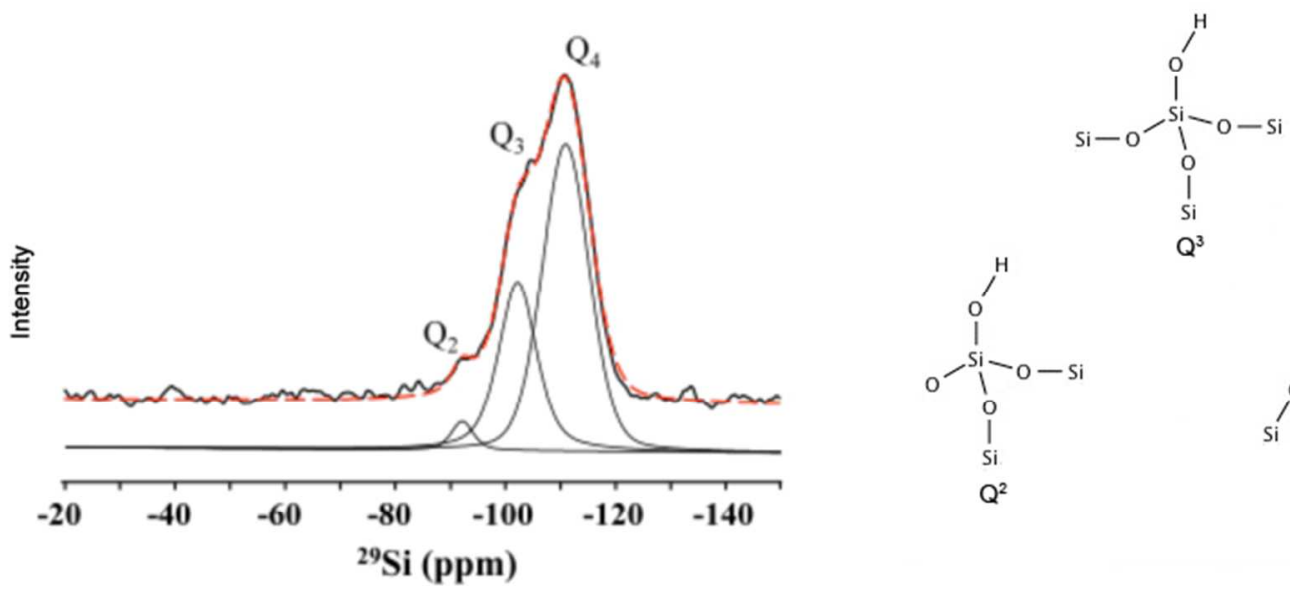

Figure 4: The allocation of the $\mathrm{Q}^{2}, \mathrm{Q}^{3}$ and $\mathrm{Q}^{4}$ site on the NMR spectra of the MCM and SBA materials.

From the integration of the three different peaks obtained in each sample it has been possible to estimate the relative amount of each species. The quantification results are then presented in table 3 .

Table 3: The silanol number and the $\mathrm{Q}^{2}, \mathrm{Q}^{3}$ and $\mathrm{Q}^{4}$ species in the material.

\begin{tabular}{|c|c|c|c|c|c|c|c|}
\hline & 1 & 2 & 3 & 4 & 5 & 6 & 7 \\
\hline & $\begin{array}{l}\text { Silanol } \\
\text { content (IR) }\end{array}$ & & & $\begin{array}{l}\mathrm{SiO}_{3} \mathrm{OH} \\
(\%)\end{array}$ & $\begin{array}{l}\mathrm{SiO}_{2}(\mathrm{OH})_{2} \\
(\%)\end{array}$ & $\begin{array}{ll}\text { Total } & \mathrm{SiOH} \\
\text { ratio } & \end{array}$ & $\begin{array}{l}\text { Condensation } \\
\text { degree }\end{array}$ \\
\hline Material & $\begin{array}{l}\alpha_{\mathrm{OH}} \\
(\mathrm{mmol} / \mathrm{g})\end{array}$ & $\mathrm{Q}^{3} / \mathrm{Q}^{4}$ & $\mathrm{Q}^{2} / \mathrm{Q}^{4}$ & $\begin{array}{l}Q^{3} / \\
\left(Q^{2}+Q^{3}\right)\end{array}$ & $\begin{array}{l}Q^{2} / \\
\left(Q^{2}+Q^{3}\right)\end{array}$ & $\begin{array}{l}\left(Q^{2}+Q^{3}\right) / \\
\left(Q^{2}+Q^{3}+Q^{4}\right)\end{array}$ & $\begin{array}{l}\mathrm{Q}^{4} / \\
\left(\mathrm{Q}^{2}+\mathrm{Q}^{3}+\mathrm{Q}^{4}\right)\end{array}$ \\
\hline SBA-15 & 3.5 & 0.30 & 0.04 & 88 & 12 & 0.25 & 0.75 \\
\hline SBA-16 & 8.3 & 0.52 & 0.02 & 96 & 4 & 0.35 & 0.65 \\
\hline MCM-41 & 3.6 & 0.62 & 0.04 & 94 & 6 & 0.40 & 0.60 \\
\hline MCM-48 & 5.2 & 0.67 & 0.04 & 94 & 6 & 0.42 & 0.58 \\
\hline MCM-41(SD) & 3.2 & 0.35 & 0.01 & 97 & 3 & 0.26 & 0.74 \\
\hline
\end{tabular}

Column 1 shows the silanol concentration acquired with infrared spectroscopy. This is the total silanol content, so both the surface silanols as the ones in the wall. A general trend visible in these 
data is that thick walled materials (SBA type materials) exhibit a higher number of total silanol groups. Columns 2 and 3 depict the $\mathrm{Q}^{3}: \mathrm{Q}^{4}$ and $\mathrm{Q}^{2}: \mathrm{Q}^{4}$ ratios of the various materials. The thinwalled MCM materials exhibit a much higher percentage of surface silicon atoms, due to thinner walls. A rough estimate of the percentage of surface silicon atoms is shown in the supplementary information (table S1). They therefore also have a much higher percentage of $\mathrm{Q}^{3}$-sites that the thick-walled SBA-type materials. Since silanol groups are preferentially at the surface it can be understood that MCM materials exhibit a slightly higher $\mathrm{Q}^{3}: \mathrm{Q}^{4}$ ratio than SBA materials. Columns 4 and 5 depict the separate percentages of $\mathrm{SiO}_{2}(\mathrm{OH})_{2}$ and $\mathrm{SiO}_{3} \mathrm{OH}$ species respectively indicated as geminal and single silanols. The total percentage of hydroxylated silicon atoms $\left(\mathrm{SiO}_{2}(\mathrm{OH})_{2}+\right.$ $\mathrm{SiO}_{3} \mathrm{OH}$ ) is shown in column 6 . The last column (7) is the complement of the total percentage of hydroxylated silicon atoms and is designated as the condensation degree. The condensation degree is larger for hydrothermally synthesized SBA materials in comparison with hydrothermal MCM materials.Because the wall thickness of SBA materials is higher than MCM materials this indicates that the total amount of hydroxylated silicon atoms lowers with the wall thickness. Therefore it can be concluded that the main part of the silanol groups is situated at the pore wall/air interface.

Remarkably the spray dried MCM-41 has a higher condensation degree than the other MCMtype materials. This higher degree of condensation cannot be correlated to the wall thickness, because this is comparable with the other MCM type materials. However, this can be explained by the synthesis procedure. During the spray drying process, sol droplets are atomized and evaporated at $220^{\circ} \mathrm{C}$. This is a much higher condensation temperature than for the hydrothermal synthesis of MCM and SBA type materials, that typically does not exceed $110^{\circ} \mathrm{C}$. Additionally the ageing step usually applied to promote further condensation and reordering of the structure after precipitation is not present in spray dried samples. This high temperature of spray drying combined with the rapid and constant evaporation of the solvent and the ethanol produced by the 
hydrolysis of the ethoxy functions of the silane, will eventually result in a higher degree of condensation.

\subsubsection{The OH-species for ethene PMOs}

In comparison with the chemical shifts of the silicon atoms of pure silica materials in ${ }^{29} \mathrm{Si} \mathrm{MAS}$ NMR, a significant and distinct shift occurs for organosilica materials. Typically, the signals for the silicon atoms with attached ethene bridges are located between -60 and -90 ppm.[45] The spectrum and a schematic overview of the different $\mathrm{T}$ sites are depicted in figure 5. No Q-sites were measured which indicates that no ethene bridges were broken during the synthesis of the silica material.
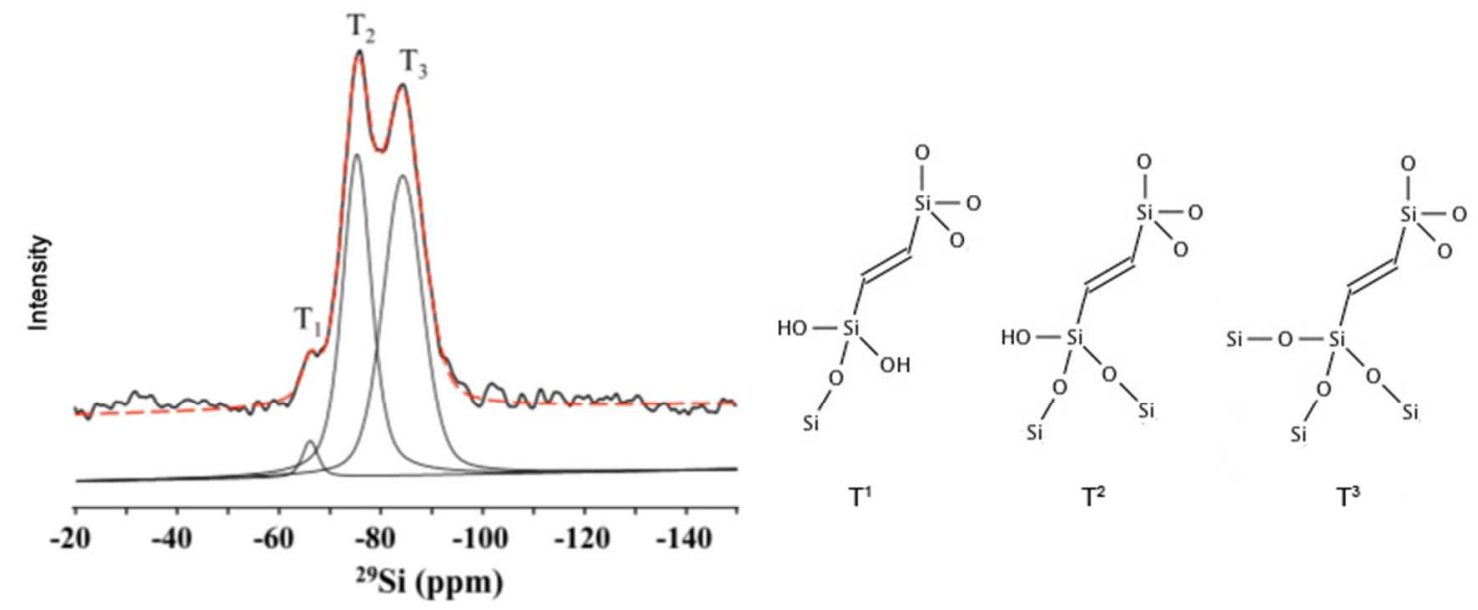

Figure 5: The allocation of the $\mathrm{T}^{1}, \mathrm{~T}^{2}$ and $\mathrm{T}^{3}$ site on the NMR spectra of the PMO material.

Table 4 depicts the quantified silicon species from this spectrum. Column 1 repeats the total silanol number obtained with in-situ IR spectroscopy. Columns 2 and 3 show the $\mathrm{T}^{2}: \mathrm{T}^{3}$ and $\mathrm{T}^{1}: \mathrm{T}^{3}$ ratios of the ethene PMO material. Columns 4 and 5 give the respective percentages of single $\left(\mathrm{T}^{2}\right)$ and geminal $\left(\mathrm{T}^{1}\right)$ silanol groups. Column 6 depicts the total percentage of hydroxylated silicon atoms and column 7 is the complement of this value, designated as the degree of condensation. 
When the total amount of $\mathrm{OH}$ species (columns 1 and 6) is compared to these on pure silica materials (table 3: columns 1 and 6), there are more hydroxyl groups present in the organosilica material. This is reflected in a much lower (below 50\%) degree of condensation (column 7). Two different mechanisms lead to these differences. First of all the polycondensation reaction of the ethene bridged precursor molecule does not progress to completion because there are six siloxane bridges to be formed per precursor molecule instead of the four of TEOS. (See the $\mathrm{T}^{3}$ sites in Figure 5). This is sterically more difficult than the polycondensation reaction with TEOS, used in the synthesis of MCM and SBA type materials. The second and probably the largest influence on the degree of condensation, is the temperature of the post treatment. While pure silica materials are calcined at $550^{\circ} \mathrm{C}$, organosilicas are obviously not. The surfactant that acts as the porogen inside the Periodic Mesoporous Organosilicas is typically extracted by Soxhlet extraction with acetone or ethanol. [41] The materials are never exposed to temperatures above $120^{\circ} \mathrm{C}$. When PMOs are treated at temperatures above $200^{\circ} \mathrm{C}$, the residual silanols will be further reduced by interaction with the ethene bridge, via an autohydrophobisation reaction, as described by Ozin [46] and Vercaemst [47]. These reactions can be shown as follows: 
A<smiles>CCCO[Si](O)(O)O[Si](O)(O)O[PH3+]</smiles><smiles></smiles>

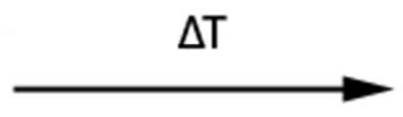<smiles>C=C[Si](O)(O)O[Si](O)(O)/C=C/[Si](O)(O)O[Si](O)(O)O</smiles>

Figure 6: The polycondensation of silicates $(A)$ and the autohydrophobisation illustrated for ethene PMOs (B).

Finally, as the temperature reaches $300^{\circ} \mathrm{C}$, the organic bridges will be destroyed.

Table 4: The silanol number and the $\mathrm{T}^{1}, \mathrm{~T}^{2}$ and $\mathrm{T}^{3}$ species in the material.

\begin{tabular}{|c|c|c|c|c|c|c|c|}
\hline & 1 & 2 & 3 & 4 & 5 & 6 & 7 \\
\hline & $\begin{array}{l}\text { Silanol } \\
\text { number (IR) }\end{array}$ & & & $\begin{array}{l}\mathrm{SiO}_{2} \mathrm{OH} \\
(\%)\end{array}$ & $\begin{array}{l}\mathrm{SiO}_{1}(\mathrm{OH})_{2} \\
(\%)\end{array}$ & $\begin{array}{l}\text { Total } \\
\text { ratio }\end{array}$ & $\begin{array}{l}\text { Condensatio } \\
\text { n degree }\end{array}$ \\
\hline Material & $\begin{array}{l}\alpha_{\mathrm{OH}} \\
(\mathrm{mmol} / \mathrm{g})\end{array}$ & $\mathrm{T}^{2} / \mathrm{T}^{3}$ & $\mathrm{~T}^{1} / \mathrm{T}^{3}$ & $\begin{array}{l}\mathrm{T}^{2} / \\
\left(\mathrm{T}^{1}+\mathrm{T}^{2}\right)\end{array}$ & $\begin{array}{l}\mathrm{T}^{1} / \\
\left(\mathrm{T}^{1}+\mathrm{T}^{2}\right)\end{array}$ & $\begin{array}{l}\left(\mathrm{T}^{1}+\mathrm{T}^{2}\right) / \\
\left(\mathrm{T}^{1}+\mathrm{T}^{2}+\mathrm{T}^{3}\right)\end{array}$ & $\begin{array}{l}\mathrm{T}^{3} / \\
\left(\mathrm{T}^{1}+\mathrm{T}^{2}+\mathrm{T}^{3}\right)\end{array}$ \\
\hline EthenePM & 16.9 & 1.16 & 0.06 & 95 & 5 & 0.55 & 0.45 \\
\hline
\end{tabular}

3.4 Determination of the maximum loading of the probing molecules

The maximum loading of the materials was determined via the grafting procedure of three silanes that differ in carbon chain length. Through the accessible silanol groups, the probing molecules were anchored to the surface. The amount of probing molecules was quantified on the carbon amount determined with elemental analysis. 
Table 6 depicts the loading capacity of the various (organo)silica materials for a trimethylsilyl (C3), an octyldimethylsilyl (C8) and an octadecyldimethylsilyl (C18) group. The pore diameter has been added for reference. From this table it can be observed that for the same reaction time the amount of grafted groups drops with the length of the aliphatic chain. When the hydrothermally synthesized pure silica materials are compared, the general tendency is that with smaller pores a lower amount of groups are grafted on the surface (MCM vs SBA vs Nucleosil). The same tendency has been shown as a function of the pore size of MCM materials by Waksburg et al.[48]

A first interesting observation can be made when SBA-15 is compared with SBA-16 and MCM-41 with MCM-48. The cubical pore systems (SBA-16 and MCM-48) systematically have a larger amount of C18 groups anchored to the surface. This is due to the fact that a cubical pore system is accessible from three dimensions while a hexagonal pore system just from one dimension. Therefore it is clear that the inside of an SBA-16 and an MCM-48 particle can be reached more easily and thus faster than the inside of an SBA-15 and MCM-41 particle. This easy access to the whole of the pore system from multiple dimensions is the reason the carbon loading on cubic pore systems is higher than the loading on hexagonal pore systems. The difference between the hexagonal and the cubical system is higher for the SBA materials than for the MCM materials. A possible explanation for this might be that in the case of SBA-16 some trapping of the C18 chains into the pores occurs as SBA-16 has an Im3m cage like pore system. This would not happen in the MCM-48 system because it does not have a central cage with smaller pore windows, but can be described as a single sheet that winds though space following a gyroid surface.[49]

This theory is confirmed by Nucleosil where the amount of grafted groups per $\mathrm{nm}^{2}$ is much higher in comparison with the other materials. The Nucleosil material consists of perfect spheres with large disordered pores $(\sim 30 \mathrm{~nm})$. This much higher loading for Nucleosil confirms that the grafting procedure for porous systems is strongly diffusion regulated. The influence of diffusion is 
larger for the longer and more bulky grafting molecules than for the smaller ones and is larger for the hexagonal one-dimensional pore systems than for the cubic three-dimensional pore systems.

However when the molar amount of groups per weight unit (mmol/g) is considered it is immediately clear that the ordered mesoporous materials exhibit a much higher loading than the commercial Nucleosil material.

Table 5: Overview of the micropore volume $\left(\mathrm{Vp}_{\mu, t-p l o t}\right)$ and surface area $\left(\mathrm{SA}_{\mu, \mathrm{t}-\mathrm{plot}}\right)$ by t-plot analysis; the mesopore volume $\left(\mathrm{Vp}_{\mathrm{m}, \mathrm{BJH}}\right)$ and surface area $\left(\mathrm{SA}_{\mathrm{m}, \mathrm{BJH}}\right)$ by $\mathrm{BJH}$ analysis; the total pore volume $\left(\mathrm{V}_{\mathrm{p}, 0.95)}\right.$ taken at $\mathrm{P} / \mathrm{P}^{\circ}=0.95$ and surface area $(\mathrm{SABET})$ by BET analysis of SBA-15, SBA-16 and ethene PMO.

\begin{tabular}{|l|l|l|l|l|l|l|}
\hline Material & SA & $\mathrm{SA}_{\mu, \mathrm{t}-\mathrm{plot}}$ & $\mathrm{SA}, \mathrm{BJH}$ & $\mathrm{V}_{\mathrm{p}, 0.95}$ & $\mathrm{Vp}_{\mu, \mathrm{t}-\mathrm{plot}}$ & $\mathrm{Vp}_{\mathrm{m}, \mathrm{BJH}}$ \\
\hline & $\mathrm{m}^{2} / \mathrm{g}$ & $\mathrm{m}^{2} / \mathrm{g}$ & $\mathrm{m}^{2} / \mathrm{g}$ & $\mathrm{cm}^{3} / \mathrm{g}$ & $\mathrm{cm}^{3} / \mathrm{g}$ & $\mathrm{cm}^{3} / \mathrm{g}$ \\
\hline SBA-15 & 655 & 460 & 429 & 0.84 & 0.07 & 0.74 \\
\hline SBA-16 & 738 & 469 & 398 & 0.63 & 0.11 & 0.47 \\
\hline EthenePMO & 923 & 649 & 598 & 0.99 & 0.07 & 0.87 \\
\hline
\end{tabular}

A second observation is the higher surface silanol loading of the SBA-type materials, compared to the MCM-type materials, regardless of the mesoscopic structure. This is particulary evident for the silanols that are accessible to the smallest silanes (C3, HMDS). This fact finds its origin in the synthesis methods. The SBA-type materials are synthesized by Pluronic surfactants, which are ethyleneoxide/propyleneoxide triblock copolymers. The ethenylene oxide side chains create microporous perforations in the SBA-walls. The SBA-type materials (and the PMO material that was also synthesized using the Pluronic 123 surfactanct) therefore have an important fraction of micropores.[50] Table 5 shows an overview of the micropore volume and and micropore surface area of these materials. It is clear that these micropores contribute very significantly to the total pore area and lie at the origin of the higher concentration of surface 
accessible silanols. Note that the difference between the BET surface area and the sum of the micropore and the mesopore surface area based on the t-plot and BJH models respectively lies within the typical error of analysis.

Table 6: The loading capacity for relevant chromatographic groups for various ordered mesoporous (organo)silica materials.

\begin{tabular}{|l|l|l|l|l|l|l|l|}
\hline Material & Pore size & \multicolumn{2}{l}{ C3 } & C8 & \multicolumn{2}{l|}{ C18 } \\
\hline & $\mathrm{nm}$ & $\mathrm{mmol} / \mathrm{g}$ & groups $/ \mathrm{nm}^{2}$ & $\mathrm{mmol} / \mathrm{g}$ & groups $/ \mathrm{nm}^{2}$ & $\mathrm{mmol} / \mathrm{g}$ & groups $/ \mathrm{nm}^{2}$ \\
\hline SBA-15 & 6.9 & 1.8 & 1.7 & 0.7 & 0.7 & 0.1 & 0.1 \\
\hline SBA-16 & 6.2 & 2.3 & 1.9 & 0.8 & 0.7 & 0.5 & 0.4 \\
\hline MCM-41 & 2.9 & 2.2 & 1.2 & 0.9 & 0.5 & 0.4 & 0.2 \\
\hline MCM-48 & 2.8 & 2.5 & 1.2 & 1.2 & 0.6 & 0.5 & 0.3 \\
\hline MCM-41(SD) & 2.9 & 1.9 & 1.6 & 1.0 & 0.8 & 0.3 & 0.3 \\
\hline EthenePMO & 6.2 & 1.1 & 0.7 & 0.8 & 0.5 & 0.4 & 0.2 \\
\hline Nucleosil & $\sim 30$ & 0.4 & 2.8 & 0.5 & 3.3 & 0.3 & 1.9 \\
\hline
\end{tabular}

\subsection{Computational considerations}

To get a better view on the behavior of silane groups on the silica surface, theoretical calculations were performed to determine the geometry of a carbon chain substituent. All results were obtained with the gaussian09 software package [51] using a B3LYP functional [52, 53] with a 3-21G Pople basis set. Since the primary focus was set on determining geometries this level of theory was chosen.

First, a random silica slab was made with approximately 5.3 hydroxyl groups per nm². This model is designed to represent an amorphous silica surface, thus a random cluster was built with the required silanol-density. To calculate the density the total number of hydroxyl groups was 
divided by the exposed surface of the cluster, hydroxyl groups at the edge are only counted as half since they are also part of neighboring clusters. The proposed approach was chosen since there are no surface models available for silicas with this high silanol loading. The edges of the slab are saturated with hydrogen atoms, which were unrestricted during the optimization. One of the hydroxyl groups was exchanged with a C8 silane group. Geometry optimizations with the described methodology show the tail is oriented to minimize the interactions with the surface. This is as expected, since the apolar tail cannot interact with the polar surface (Figure 7).
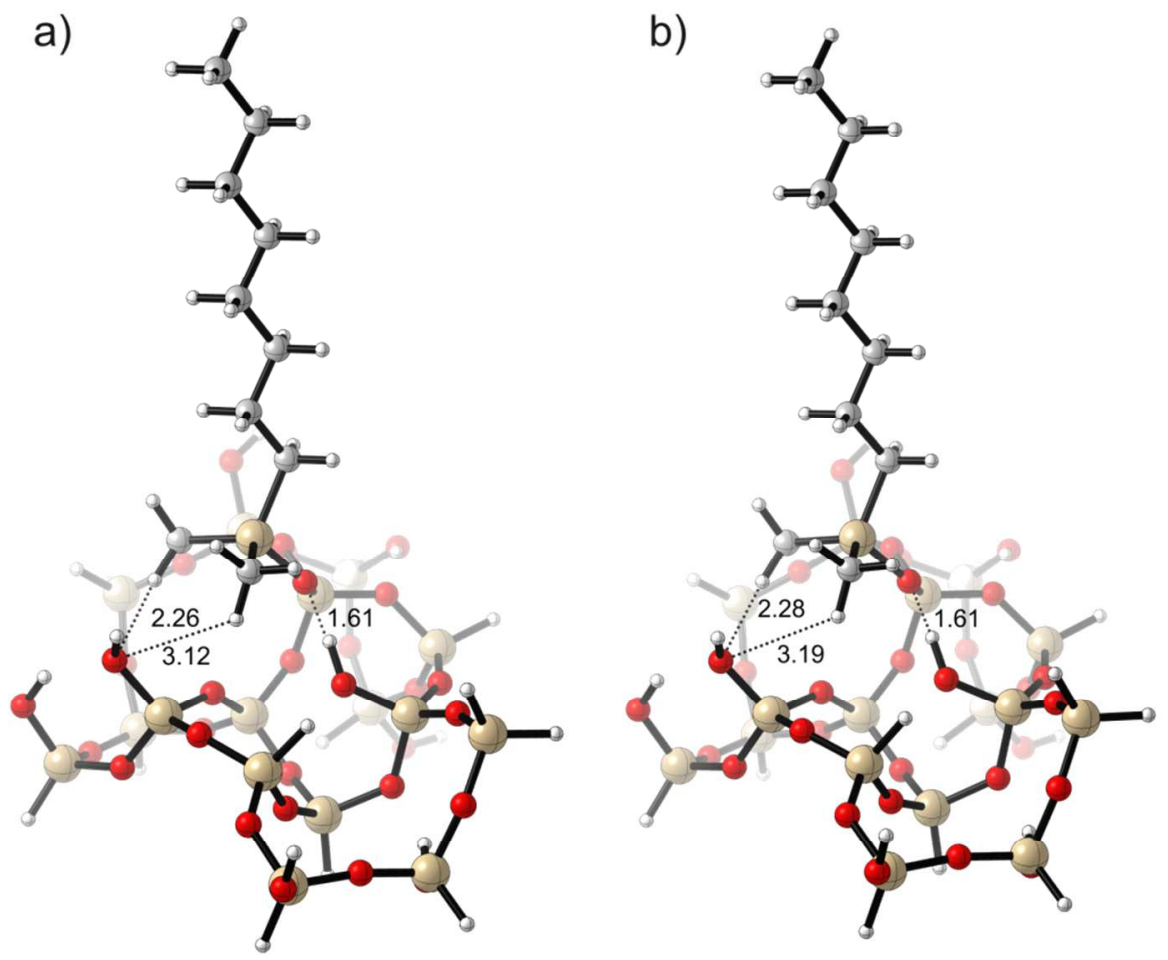

Figure 7: Random silica surface with 5.3 hydroxyl group per $\mathrm{nm}^{2}$ and one C8 silane substituent. This silane blocks two neighboring silanol groups. Figure a) is without an implicit solvent model, b) is the same starting geometry optimized with such a model. The differences are minimal.

Similar calculations, where an implicit solvent model (IEFPCM[54]) was added, characterized by the dielectric constant of toluene, gave comparable results. The geometrical results show that only the - $\mathrm{Si}\left(\mathrm{CH}_{3}\right)_{2}-$ moiety imposes a limit on the number of possible substituents per surface area. From the result it can be seen that the $-\mathrm{Si}\left(\mathrm{CH}_{3}\right)_{2}$ - moiety blocks at least two extra hydroxyl 
groups. Since those groups can also be overlapped by another silane group from a more distant position, they are only counted as half. So it can be concluded that, on this dense cluster, at least two groups are needed to accommodate the substituent leading to a maximum possible loading of 2.65 groups per $\mathrm{nm}^{2}$. On a less dense surface with about 2.5 hydroxyl groups per $\mathrm{nm}^{2}$ there are no neighboring positions blocked (Figure 8).

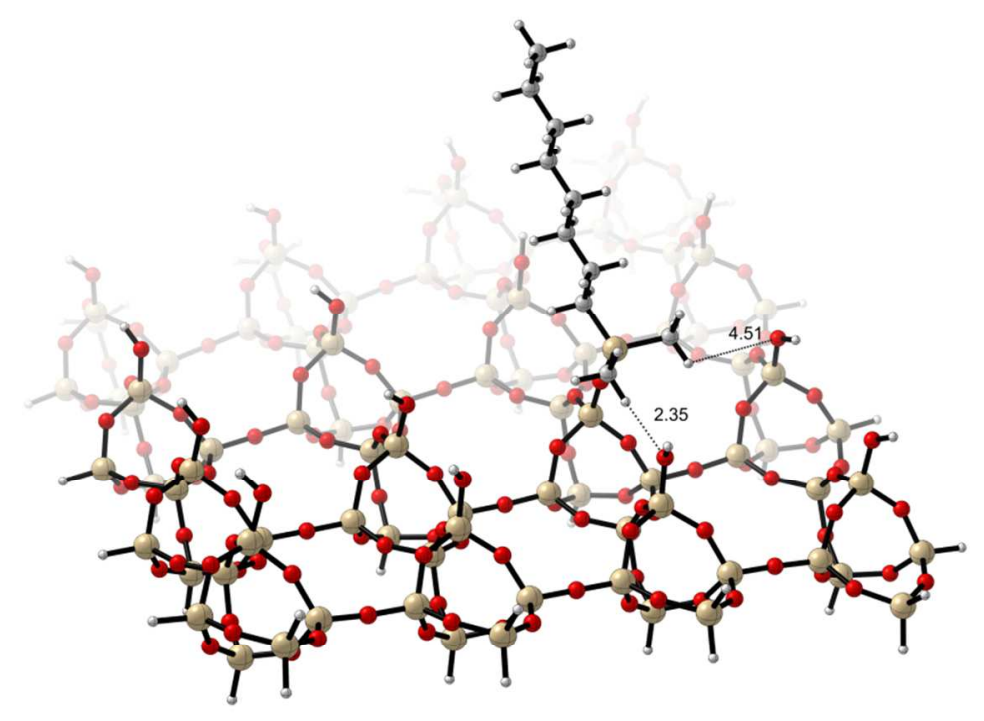

Figure 8: Surface model with about 2.5 hydroxyl groups per $\mathrm{nm}^{2}$ the surface is based on an ordered silica slab. The silane group is close to a neighboring hydroxyl group, but since the surface is more open this does not block the site. As an upper bound, on this type of surface it is possible to have 2.5 silane substituents per $\mathrm{nm}^{2}$. However, when the surface is almost full, the close interaction $(2.35 \AA ̊)$ will fully shield one of the hydroxyl groups and the theoretical maximum will never be reached.

This means the theoretical density in this case is 2.5 groups per $\mathrm{nm}^{2}$. On average, 2.5 groups per $\mathrm{nm}^{2}$ is the theoretical maximal loading on a silica surface with only single silanols present, this is close to the value that can be estimated from the kinetic diameter of the silane and that was reported previously by Van Der Voort. [55] 
To assess the influence of geminal silanols a slight modification on the random surface was made, an extra hydroxyl group was added on a silicon atom and one Si-O-Si bond on that atom was broken. The other silicon atom was saturated by hydrogen. With this approach the surface contains a single geminal group. Two silane groups were placed on this site and after geometry optimization it appeared that at least two extra silanol groups were blocked by this. (Figure 9).

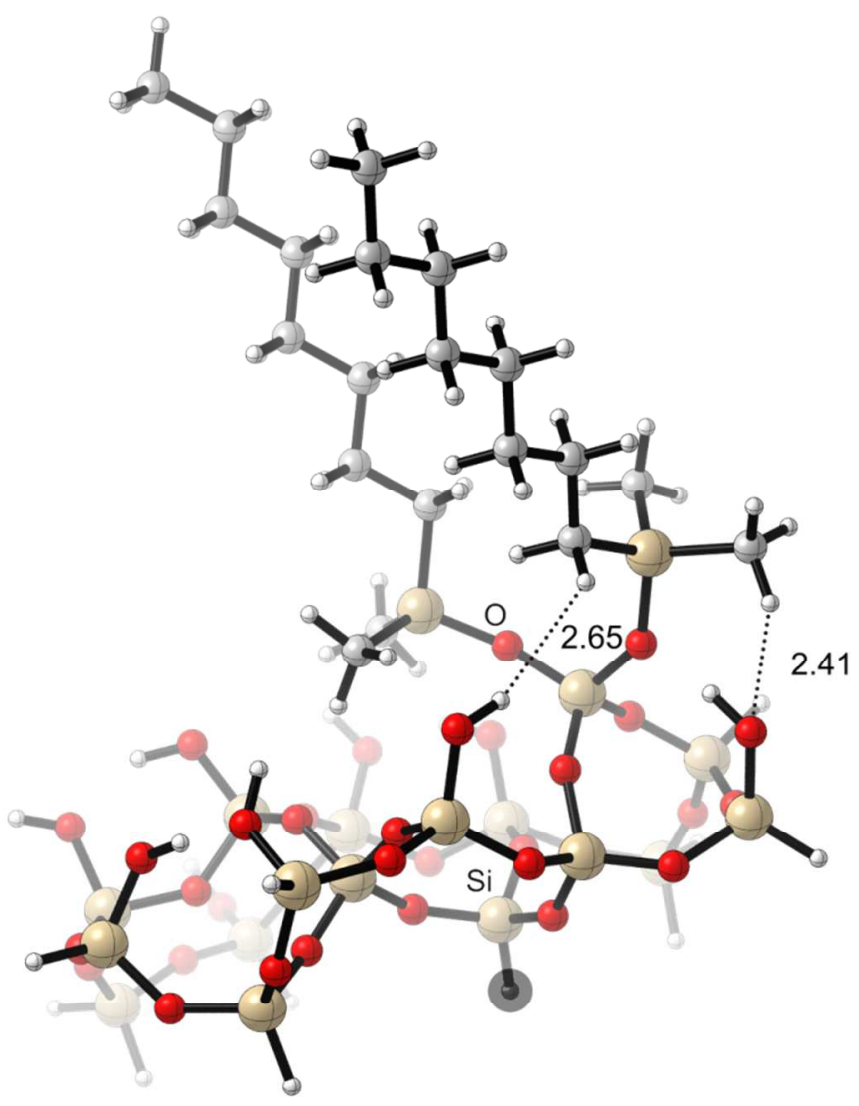

Figure 9: The original cluster is modified to incorporate a geminal silanol, the Si-O bond between the atoms explicitly named on the figure was broken and the marked hydrogen atom was added for saturation, a second silane group was then added to the free oxygen. With two silane groups on a geminal silanol two other silanol groups are blocked. This allows a more efficient stacking of the substituents. 
For the same reason as before they only count as half. With the extra hydroxyl group from the geminal silanol, the surface silanol density is 6.7 groups per $\mathrm{nm}^{2}$ (the surface area remains unchanged but an extra hydroxyl group is added). This means that when one extra hydroxyl group is blocked by the silane moiety, the density of substituents on the surface can be calculated as:

$$
\frac{2 \text { silane groups } \cdot 6.7 \mathrm{gr} / \mathrm{nm}^{2}}{3 \text { hydroxy groups }}=4.5 \mathrm{gr} / \mathrm{nm}^{2}
$$

A fully hydroxylated silica surface (single silanol groups) can have maximum of $4.6 \pm 0.5$ groups per $\mathrm{nm}^{2}$. This means that roughly only half of the single silanol groups is sterically available for grafting which coincides with previous reports on that matter.[9]

In Table 7 we summarize the total silanol number, differentiated as total, geminal and single silanols and the silanol that are accessible for the small HMDS molecule, expressed in mmol per gram and in groups per $\mathrm{nm}^{2}$.

Table 7: The bulk silanol number, the amount of single and geminal silanols and the surface silanol groups, depicted with the pore diameter $\left(d_{p}\right)$ and pore wall $(h)$.

\begin{tabular}{|l|l|l|l|l|l|l|l|}
\hline & 1 & 2 & 3 & 4 & 5 & 6 & 7 \\
\hline Material & $\begin{array}{l}\alpha_{\text {OH,bulk }} \\
(\mathrm{mmol} / \mathrm{g})\end{array}$ & $\begin{array}{l}\alpha_{\text {OH,single,bulk }} \\
(\mathrm{mmol} / \mathrm{g})\end{array}$ & $\begin{array}{l}\alpha_{\text {OH,geminal,bulk }} \\
(\mathrm{mmol} / \mathrm{g})\end{array}$ & $\begin{array}{l}\alpha_{\mathrm{OH}, \text { surface }} \\
(\mathrm{mmol} / \mathrm{g})\end{array}$ & $\begin{array}{l}\alpha_{\mathrm{OH}, \text { surface }} \\
\left(\mathrm{gr} / \mathrm{nm}^{2}\right)\end{array}$ & $\begin{array}{l}\mathrm{h} \\
(\mathrm{nm})\end{array}$ & $\begin{array}{l}\mathrm{d}_{\mathrm{p}} \\
(\mathrm{nm})\end{array}$ \\
\hline SBA-15 & 3.5 & 3.1 & 0.4 & 1.9 & 1.7 & 4.2 & 6.9 \\
\hline SBA-16 & 8.3 & 8.0 & 0.4 & 2.3 & 1.9 & 6.4 & 6.2 \\
\hline MCM-41HT & 3.6 & 3.4 & 0.2 & 2.3 & 1.2 & 1.1 & 2.9 \\
\hline MCM-48 & 5.2 & 4.9 & 0.2 & 2.6 & 1.2 & 1.0 & 2.8 \\
\hline MCM-41SD & 3.2 & 3.1 & 0.1 & 1.9 & 1.6 & 1.2 & 2.9 \\
\hline EthenePMO & 16.9 & 14.3 & 2.6 & 1.1 & 0.7 & 3.1 & 6.2 \\
\hline
\end{tabular}


The amount of single and geminal silanols (columns 2 and 3 in table 7) are calculated by multiplying the relative amount of silanols with the total number of OH-groups determined by IR spectroscopy (i.e. $\alpha_{\mathrm{OH}} \mathrm{X}\left(\mathrm{Q}^{3} /\left(\mathrm{Q}^{2}+\mathrm{Q}^{3}\right)=\alpha_{\mathrm{OH} \text {,single }}\right.$ ). This gives the absolute amount single and geminal silanols, irrespective of their location. They could be on the pore wall or in the bulk silica.

Column 4 in table 7 then shows the silanols that were available to the small HMDS (C3 silane). Because none of these values exceed the theoretical maximum values they can be considered as the "surface" or "reachable" silanols.

4 Conclusion

We have established that the amount of silane groups (expressed as groups per $\mathrm{nm}^{2}$ ) that can be grafted on the surface of ordered mesoporous silicas (MCM-41, MCM-48, SBA-15, SBA-16) is much smaller than on the surface of the commercial materials, which are typically used as a packing material for HPLC columns. The main reason for this is that the grafting reaction is strongly diffusion limited, as the surface area of these materials is basically internal surface area.

For the mesoporous silicas, it can be concluded that the amount of surface silanols is larger for the micropore containing SBA-type materials than for the non microporous MCM-type materials. The amount of internal silanol groups is proportional, however not linearly, to the wall thickness. Silica materials with thicker walls (SBA-15, SBA-16 and ethene PMO) also have more total silanol groups than the thin walled MCM-materials. In general, for the thick walled mesoporous silicas, one should keep in mind that up to $70 \%$ of the silanols is unreachable for a small silane.

Spray dried MCM-41 exhibits a more condensed silica structure due to the higher synthesis temperature. The PMO material (ethene PMO) on the other hand exhibits a lower condensation degree. This can be attributed to the different condensation behavior of $(\mathrm{EtO})_{3}-\mathrm{Si}-\mathrm{CH}=\mathrm{CH}-\mathrm{Si}(\mathrm{OEt})_{3}$ compared to $\mathrm{Si}(\mathrm{OEt})_{4}$ and to the absence of a high temperature calcinations procedure. 
Acknowledgements:

M.I. acknowledges the IWT-Flanders (Agentschap voor Innovatie door Wetenschap en Technologie) grant nr. IWT/SB/71325 for financial support. T.B. is indebted to Ghent University, G0A-grant, project number 01G00710 and the European Research Council (FP7(2007-2013) ERC grant nr. 240483). Computational resources and services were provided by Ghent University. 
References

[1] Bartle, K.D.; Carney, R.D.; Cavazza, A.; Cikalo, M.G.; Myers, P.; Robson, M.M.; Roulin, S.C.P.; Sealey, K. J. Chrom. A 2000, 892, 279.

[2] Sindorf, D.; Maciel, G. J. Am. Chem. Soc. 1983, 105, 1487.

[3] Kratochvila, J.; Salajka, Z.; Kazda, A.; Kadlc, Z.; Soucek, J.; Georghiu, M. Journal of Non-crystalline Solids 1990, 116, 93.

[4] Kellum, G.; Smith, R. Anal. Chem. 1967, 39, 341

[5] Zhuravlev, L. Colloids and Surfaces A-Physicochemical and Engeneering Aspects $1993,74,71$.

[6] Zhuravlev, L. Langmuir 1987, 3, 316.

[7] Zhuravlev, L. Colloids and Surfaces A-Physicochemical and Engeneering Aspects $2000,173,1$.

[8] Nawrocki, J. Journal of Chromatography A 1997, 779, 29.

[9] Vansant, E.; Van Der Voort, P. ; Vrancken, K. Characterization and Chemical Modification of the Silica Surface; Studies in Surface Science and Catalysis; Elsevier Science BV, 1995; Vol. 93.

[10] Ek, S.; Root, A.; Peussa, M.; Hiinistö, L.; Thermochim. Acta, 2001, 379, 201.

[11] McCool, B.; Murphy, L.; Tripp, C.P.; J. Colloid Interf. Sci., 2006, 295, 294.

[12] Zholobenko, V.L.; Plant, D.; Evans, A.J.; Holmes, S.M.; Micropor. Mesopor. Mater., 2001, 44-45, 793. 
[13] Léonardelli, S.; Facchini, L.; Fretigny, C.; Touyne, P.; Legrand, A.P.; J. Am. Chem. Soc. $1992,114,6412$.

[14] Liu, C.C.; Maciel, G.E.; J. Am. Chem. Soc., 1996, 118, 5103.

[15] Delitala, C.; Cadoni, E.; Delpiano, D.; Meloni, D.; Alba, M.D.; Becerro, A.I.; Ferino, I., Micropor. Mesopor. Mater. 2009, 118, 11.

[16] Sindorf, D.W.; Maciel, G.E.; J. Am. Chem. Soc., 1983, 105, 3767.

[17] Park, D.; Nishiyama, N.; Egashina, Y.; Ueyama, K.; Ind. Eng. Chem. Res. 2001, 40, 6105.

[18] Knözigner, H.; Schuster, P.; Zundel, G.; Sandorfy, C.; The Hydrogen Bond, vol 3, North-Holland, Amsterdam, 1979, p1263.

[19] Kruk, M.; Antochshuk, V.; Matos, J.; Mercuri, L.; Jaroniec, M.; J. Am. Chem. Soc.2002, 124, 768.

[20] Hansen, E.; Schmidt, R.; Stöcker, M.; Akporiaye, D.; J. Phys. Chem., 1995, 99, 4148.

[21] Grünberg, B.; Emmler, T.; Gedat, E.; Shendrovich, I.; Findenegg, G.H.; Limbach, H.; Buntkowsky, G.; Chem. Eur. J., 2004, 10, 5689.

[22] Lebret, A.; Lelong, G.; Mason, P.; Saboungi, M.; Brady, J.; Food Biophysics, 2011, 6, 233.

[23] Shenderovich, I.; Buntkowsky, A.; Schreiber, A.; Gedat, E.; Sharif, S.; Albrecht, J.; Golubev, N.; Findenegg, G.; Limbach, H.; J. Phys. Chem. B, 2003, 107, 11924.

[24] Pizzanelli, S.; Kababya, S.; Frydman, V.; Landau, M.; Vega, S.; J. Phys. Chem. B, 2005, 109, 1997. 
[25] Landmesser, H.; Kosslick, H.; Fricke, R.; Solid State Ionics, 1997, 101-103, 271.

[26] Kocherbitov, V.; Alfredsson, V.; J. Phys. Chem. C, 2007, 111, 12906.

[27] Cauvel, A.; Brunel, F.; DiRenzo, F.; Garrone, E.; Fubini, B.; Langmuir, 1997, 13, 2773.

[28] Blin, J.; Carteret, C.; J. Phys Chem. C, 2007, 111, 2773.

[29] Sutra, P.; Fajula, F.; Brunel, D.; Lentz, P.; Daelen, P.; Nagy, J.; Colloids Surf. A, 1999, $158,21$.

[30] Zhao, X.; Lu, G.; Whittaker, A.; Millar, G.; Zhu, H.; J. Phys. Chem. B, 1997, 101, 6525.

[31] Llewellyn, P.; Schuth, F.; Grillet, Y.; Rouquerol, F.; Unger, K.; Langmuir, 1995, 11, 574.

[32] Trebosc, J.; Wiench, J.; Huh, S.; Lin, U.; Prusky, M.; J. Am. Chem. Soc., 2005, 127, 3057.

[33] Shenderovitch, I.; Maudu, D.; Akcakayiran, G.; Buntkowsky, G.; Limbach, H.; Findenegg, G.; J. Phys. Chem. B, 2007, 111, 12088.

[34] Gallas, J.-P.; Goupil, J.-M.; Vimont, A.; Lavalley, J.-C.; Gil, B.; Gilson, J.-P.; Miserque, 0. Langmuir 2009, 25, 5825.

[35] Zhao, D. Y.; Huo, Q. S.; Feng, J. L.; Chmelka, B. F.; Stucky, G. D. J. Am.Chem. Soc. 1998, 120,6024 .

[36] Stevens, W. J. J.; Mertens, M.; Mullens, S.; Thijs, N.; Van Tendeloo, G.; Cool, P.; Vansant, E. F. Micropor.Mesopor. Mater.2006, 93, 119.

[37] Beck, J. S.; Vartuli, J. C.; Roth, W. J.; Leonowicz, M. E.; Kresge, C. T.;Schmitt, K. D.; Chu, C. T. W.; Olson, D. H.; Sheppard, E. W.; Mc-Cullen, S. B.; Higgins, J. B.; Schlenker, J. L. J. Am. Chem. Soc. 1992, 114, 10834. 
[38] Collart, O.; Van Der Voort, P.; Vansant, E.; Desplantier, D.; Galarneau, A.; Di Renzo, F.; Fajula, F. J. Phys.Chem. B 2001, 105, 12771.

[39] Ide, M.; Wallaert, E.; Van Driessche, I.; Lynen, F.; Sandra, P.; Van Der Voort, P. Micropor. Mesopor. Mater. 2011, 142, 282.

[40] Goethals, F.; Vercaemst, C.; Cloet, V.; Hoste, S.; Van Der Voort, P.; Van Driessche, I. Micropor. Mesopor. Mater. 2010, 131, 68.

[41] Vercaemst, C.; Ide, M.; Allaert, B.; Ledoux, N.; Verpoort, F.; Van Der Voort, P.; Chem.Comm., 2007, 22, 2261.

[42] Kruk, M.; Jaroniec, M.; Sayari, A. Chem.Mater. 1999, 11, 492.

[43] Ravikovitch, P.; Neimark, A. Langmuir 2000, 16, 2419.

[44] Ravikovitch, P.; Neimark, A. Langmuir 2001, 18, 911.

[45] Vercaemst, C.; Ide, M.; Wiper, P.; Jones, J.; Khimyak, Y.; Verpoort, F.; Van Der Voort, P.; Chem. Mater., 2009, 21, 5792.

[46] Asefa, T.; MacLachlan, M.; Grondey, H.; Coombs, N.; Ozin, G.; Angewandte Chemie Int. Ed, 2000, 39, 1808.

[47] Van Der Voort, P.; Vercaemst, C.; Schaubroeck, D.; Verpoort, F.; Phys.Chem. Chem. Phys.2008, 10, 5349

[48] Waksburg, A.; Nguyen, M.-H. T.; Chaffee, A. L.; Kidder, M. K.; Buchanan, A. C., III; Britt, P. F. Molecular Simulation 2011, 37, 1266.

[49] Anderson, M.; Zeolites 1997, 19, 220.

[50] Kruk, M.; Jaroniec, M.; Hyun, C.; Ryoo, R.; Chem. Mater. 2000, 12, 1961. 
[51] M. J. Frisch, G. W. Trucks, H. B. Schlegel, G. E. Scuseria, M. A. Robb, J. R. Cheeseman, G. Scalmani, V. Barone, B. Mennucci, G. A. Petersson, H. Nakatsuji, M. Caricato, X. Li, H. P. Hratchian, A. F. Izmaylov, J. Bloino, G. Zheng, J. L. Sonnenberg, M. Hada, M. Ehara, K. Toyota, R. Fukuda, J. Hasegawa, M. Ishida, T. Nakajima, Y. Honda, O. Kitao, H. Nakai, T. Vreven, J. A. Montgomery Jr., J. E. Peralta, F. Ogliaro, M. Bearpark, J. J. Heyd, E. Brothers, K. N. Kudin, V. N. Staroverov, R. Kobayashi, J. Normand, K. Raghavachari, A. Rendell, J. C. Burant, S. S. Iyengar, J. Tomasi, M. Cossi, N. Rega, J. M. Millam, M. Klene, J. E. Knox, J. B. Cross, V. Bakken, C. Adamo, J. Jaramillo, R. Gomperts, R. E. Stratmann, O. Yazyev, A. J. Austin, R. Cammi, C. Pomelli, J. W. Ochterski, R. L. Martin, K. Morokuma, V. G. Zakrzewski, G. A. Voth, P. Salvador, J. J. Dannenberg, S. Dapprich, A. D. Daniels, O. Farkas, J. B. Foresman, J. V. Ortiz, J. Cioslowski, D. J. Fox, Revision A.02, Gaussian, Inc., Wallingford CT ed., 2009.

[52] A. D. Becke, J. Chem. Phys. 1993, 98, 5648.

[53] C. T. Lee, W. T. Yang, R. G. Parr, Phys. Rev. B 1988, 37, 785.

[54] E. Cances, B. Mennucci, J. Tomasi, J. Chem. Phys. 1997, 107, 3032.

[55] Van Der Voort, P.; Vercauteren, S.; Peeters, K.; Vansant, E.; J. Colloid. Interface Sci., $1993,157,518$.

[56] Iler, R. The Chemistry of Silica; 1979.

[57] Huo, O.; Magolese, D.I.; Ciesla, U.; Feng, P.; Gier, T.E.; Sieger, P.; Leon, R.; Petroff, P.M.; Schüth, F.; Stucky, G.D.; Nature 1994, 368, 317.

[58] Hoffmann, F.; Cornelius, M.; Morell, J.; Fröba, M.; Angewandte Chemie Int. Ed., 2006, $45,3216$. 

(top position)

\section{Glass squared pipe}

Pellet

holder

Valve(for vacuum controller)

To vacuum apparatus

Sample Furnace $\mathrm{KBr}$ windows 


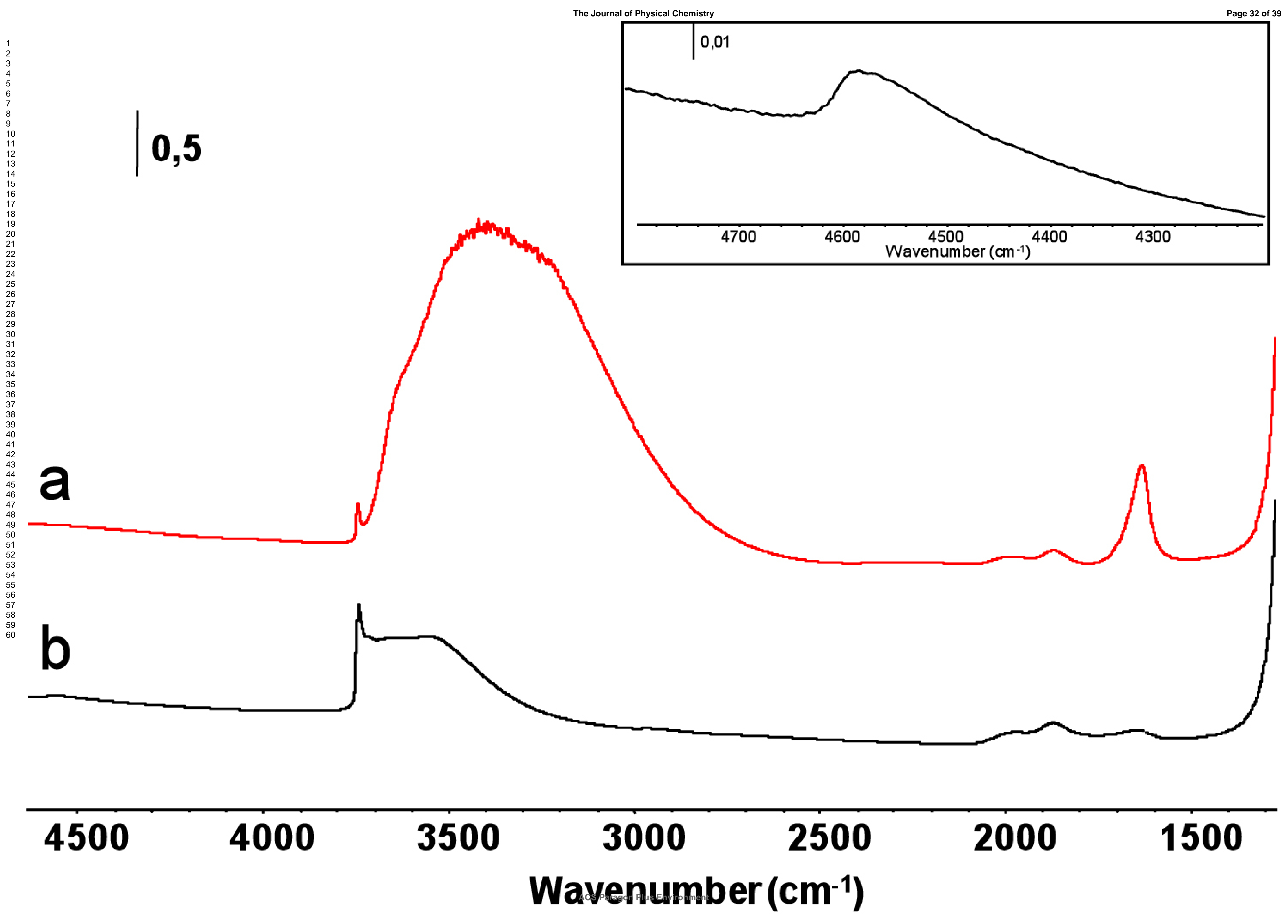




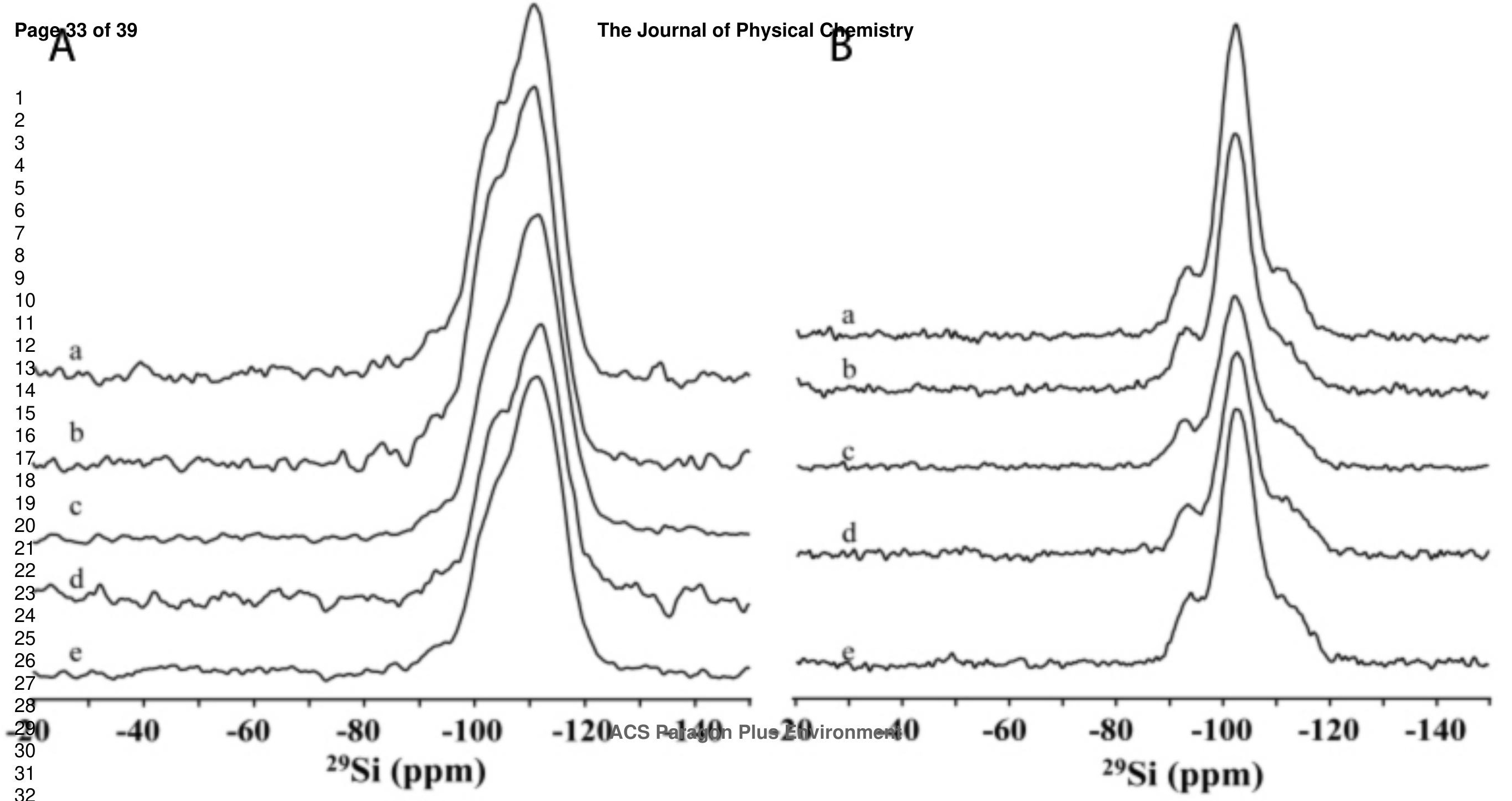




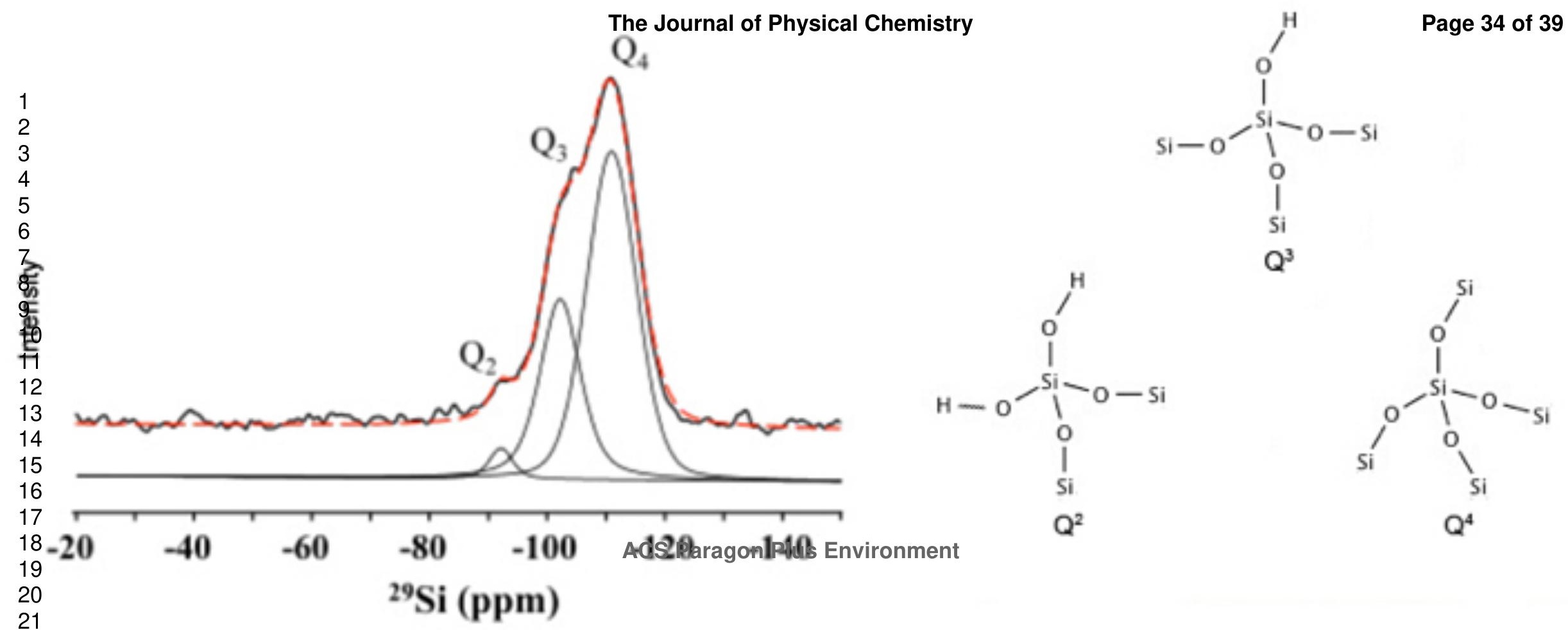




$$
\begin{array}{lll}
\text { Page } 35 \text { of } 39 & T_{2} & \text { The Journal of Physical Chemistry }
\end{array}
$$

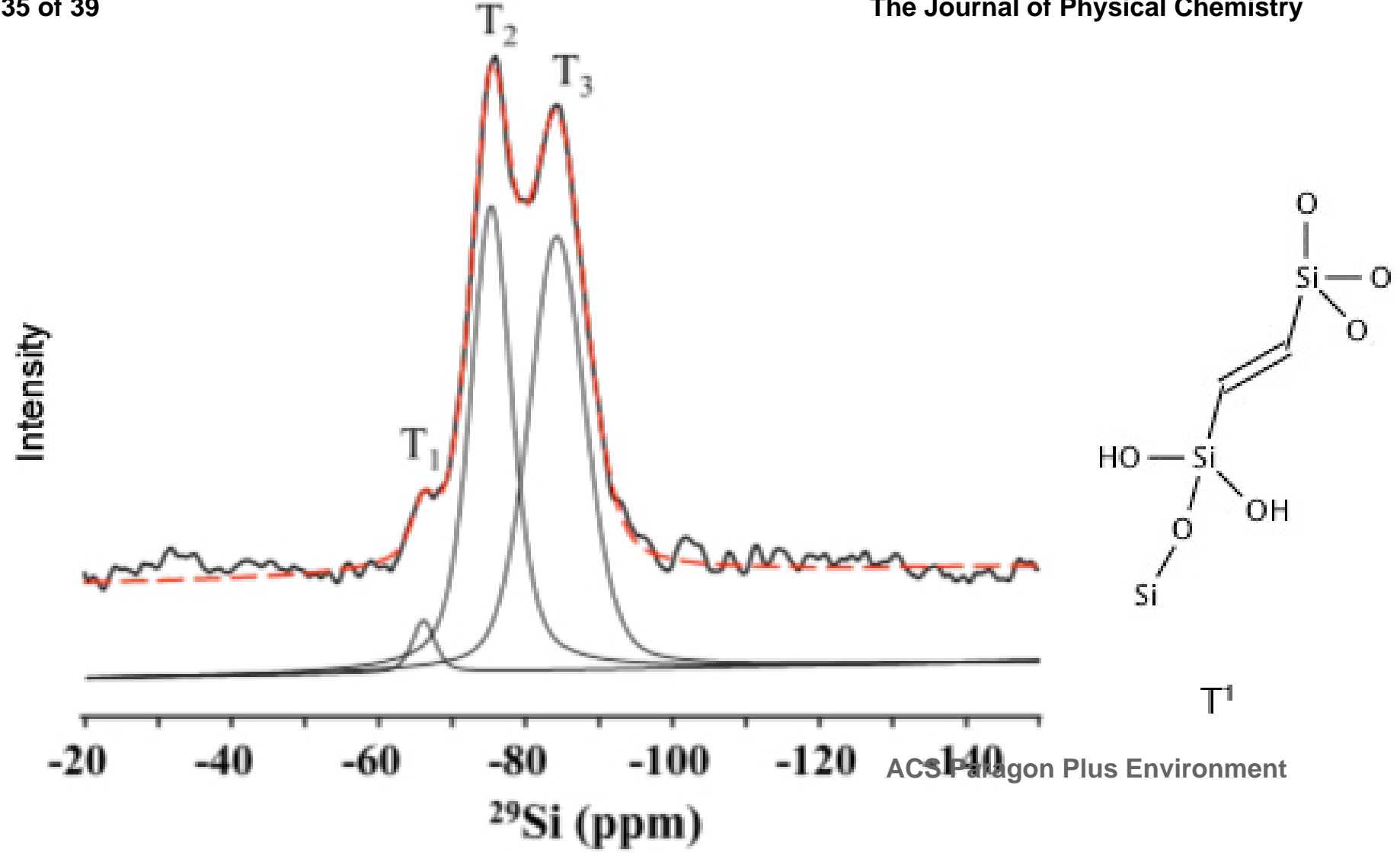

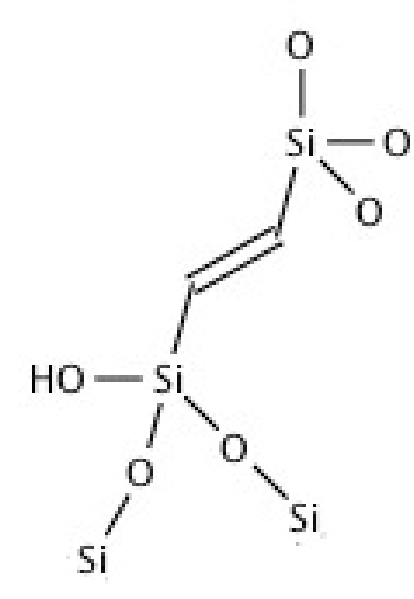

$\mathrm{T}^{2}$

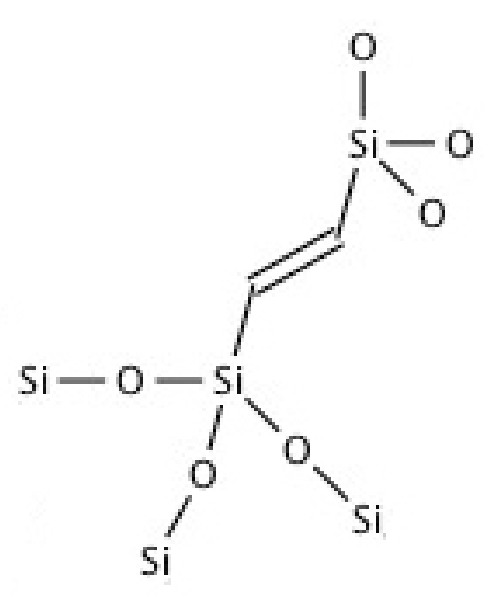

$\mathrm{T}^{3}$ 


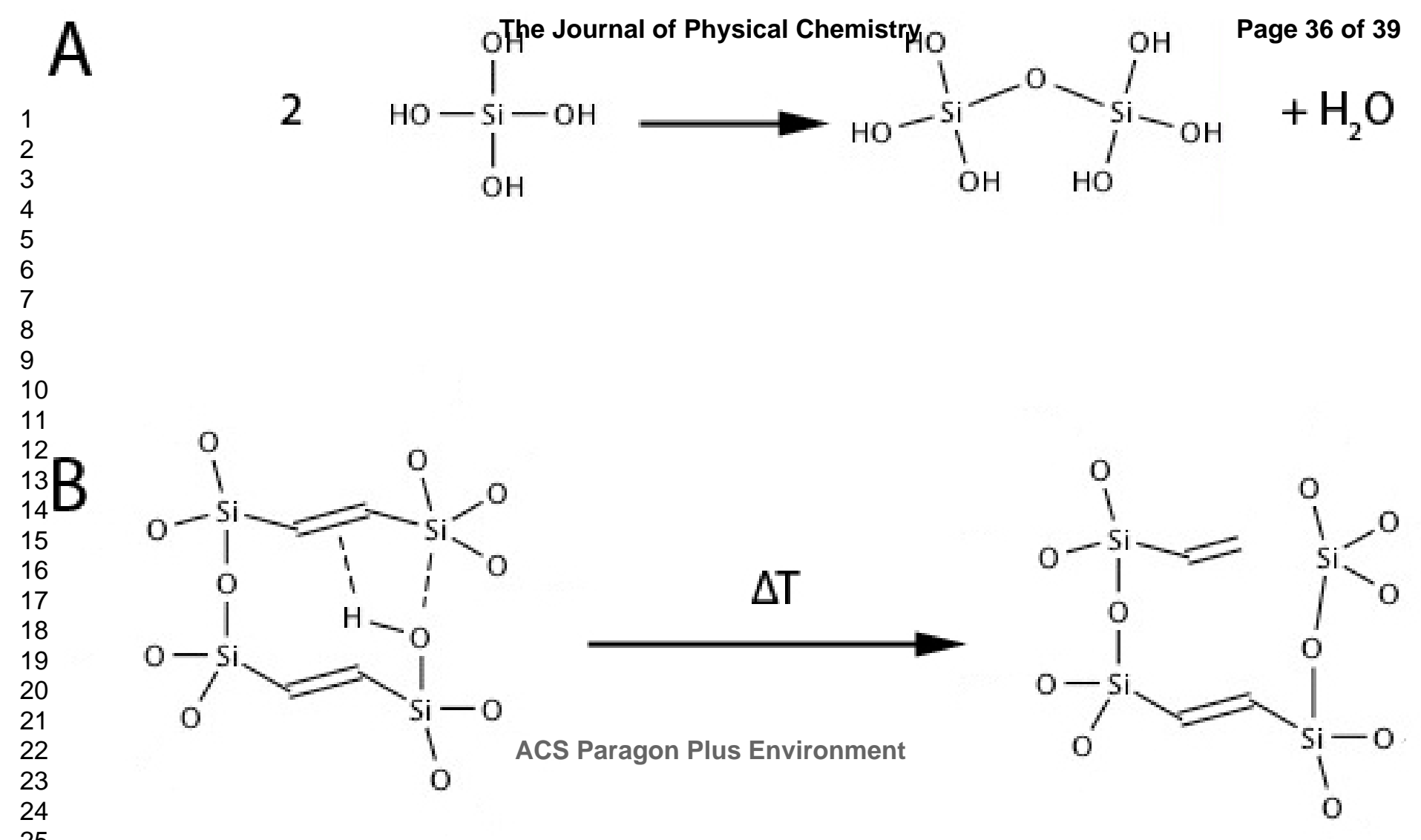




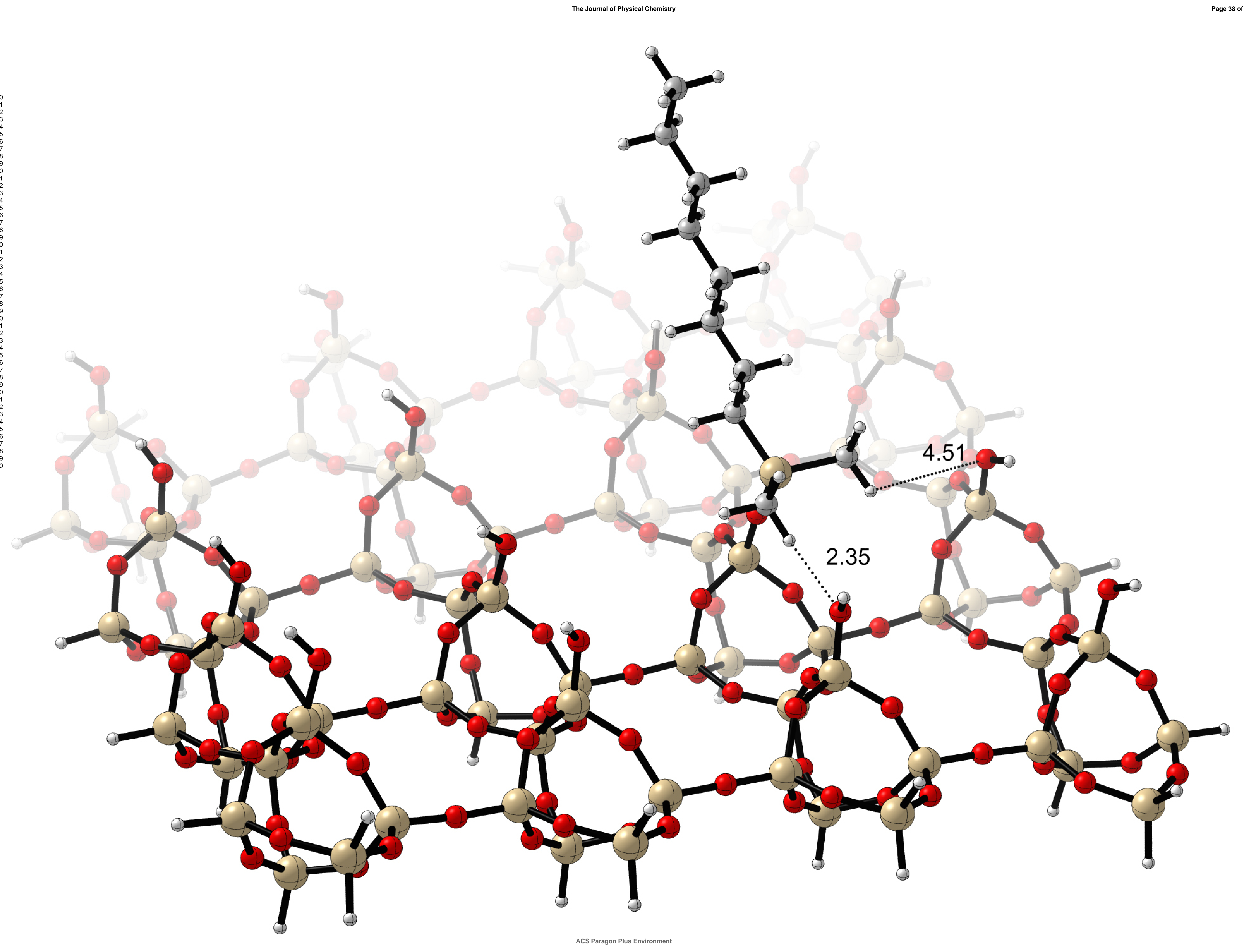


Page 39 of 39

The Journal of Physical Chemistry

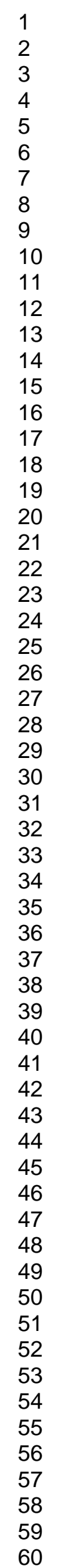

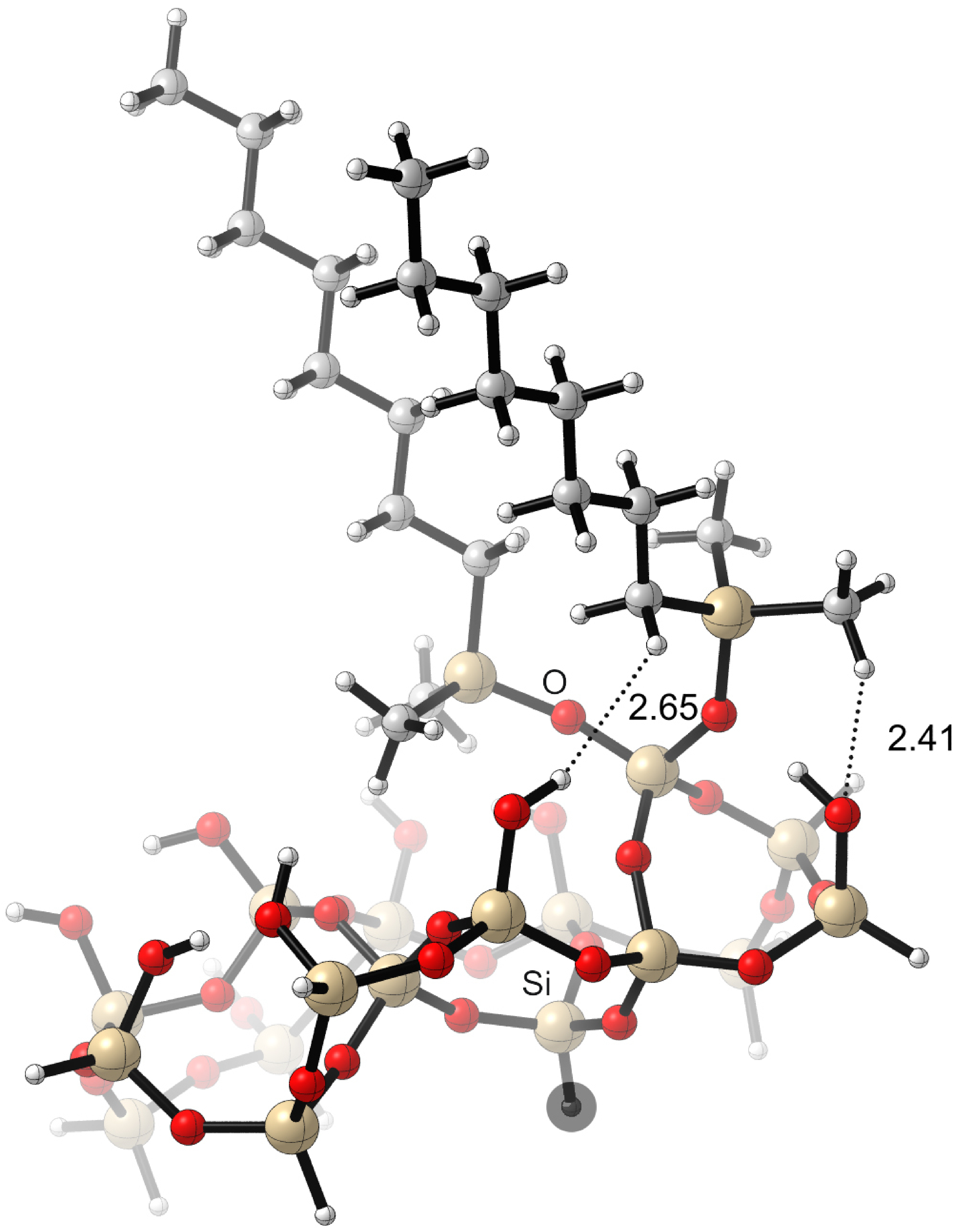

ACS Paragon Plus Environment 